FEDERAL RESERVE BANK OF SAN FRANCISCO

WORKING PAPER SERIES

\title{
Convergence and Anchoring of Yield Curves in the Euro Area
}

\author{
Michael Ehrmann \\ European Central Bank \\ Marcel Fratzscher \\ European Central Bank \\ Refet S. Gürkaynak \\ Bilkent University and CEPR \\ Eric T. Swanson \\ Federal Reserve Bank of San Francisco
}

November 2008

Working Paper 2007-24

http://www.frbsf.org/publications/economics/papers/2007/wp07-24bk.pdf

The views in this paper are solely the responsibility of the authors and should not be interpreted as reflecting the views of the Federal Reserve Bank of San Francisco or the Board of Governors of the Federal Reserve System. 


\title{
CONVERGENCE AND ANCHORING OF YiELd CuRVES IN THE EURO AREA*
}

\author{
Michael Ehrmann, \\ Marcel Fratzscher, \\ Refet S. Gürkaynak, \\ and \\ Eric T. Swanson ${ }^{* *}$
}

\begin{abstract}
We study the convergence of European bond markets and the anchoring of inflation expectations in the euro area using high-frequency bond yield data for France, Germany, Italy, and Spain as well as smaller euro area countries and a control group comprising the UK, Denmark, and Sweden. We find that Economic and Monetary Union (EMU) has led to substantial convergence in euro area sovereign bond markets in terms of interest rate levels, unconditional daily fluctuations, and conditional responses to major macroeconomic announcements. Our findings also suggest a substantial increase in the anchoring of long-term inflation expectations since EMU, particularly for Italy and Spain, which have seen their long-term interest rates become much lower, much less volatile, and much better anchored in response to news. Finally, we present evidence that the elimination of exchange rate risk and the adoption of a common monetary policy were the primary drivers of bond market convergence in the euro area, as opposed to fiscal policy restraint and the loose exchange rate peg of the 1990s.
\end{abstract}

JEL no: E52, E58

Keywords: bond markets; euro area; EMU; convergence; anchoring; credibility; monetary policy.

7 November 2008

\footnotetext{
* We thank Roberto Blanco, Vincent Brousseau, Aviram Levy, Michal Nielsen, and Marcello Pericoli for help with the data, David Thipphavong for research assistance, and Carlo Favero, Mark Fisher, Philipp Hartmann, Jonathan Wright, and seminar participants at Bilkent, Bocconi, Bogazici, Koc, and Pompeu Fabra Universities, the European Economic Association Meetings, the Cambridge/RPI/Atlanta Fed Conference on Financial Market Integration, and the Münster workshop on The First Decade of European Monetary Union, as well as two referees and the editor, for helpful discussions, comments, and suggestions. Gürkaynak's research was supported by a European Central Bank Lamfalussy Fellowship and a TUBAGEBIP grant from the Turkish Academy of Sciences. The views expressed in this paper are solely those of the authors and do not necessarily reflect the views of the European Central Bank, the management of the Federal Reserve Bank of San Francisco, or any other person within the European Central Bank or Federal Reserve system.

** Ehrmann: European Central Bank; michael.ehrmann@ecb.int

Fratzscher: European Central Bank; marcel.fratzscher@ecb.int

Gürkaynak: Bilkent University and CEPR; refet@bilkent.edu.tr

Swanson: Federal Reserve Bank of San Francisco; eric.swanson@sf.frb.org
} 


\section{Introduction}

To what extent has Economic and Monetary Union (EMU) in Europe been successful? Answering this question requires defining what it means for EMU to be "successful". In this paper, we focus on the monetary union aspects of the EMU, in particular, the extent to which monetary union led to integration of bond markets across euro area countries and the effects it had on the anchoring of long-term inflation expectations within those countries. These two dimensions of monetary policy in the euro area are intimately related because long-term bond yields in any given country are very sensitive to financial market expectations about long-run inflation. Indeed, our analysis in this paper will focus on the insights that one can draw about the monetary union and monetary policy from the high-frequency behavior of euro area bond yields.

First, we investigate to what extent the sovereign bond markets in France, Germany, Italy and Spain, the four largest euro area countries, have become integrated along with the unification of their currencies and monetary policies. It is not clear that a common currency and monetary policy necessarily leads to an integrated bond market-for example, differences in default risk across countries or differences in liquidity could imply substantial differences in yield spreads across countries and over time. Indeed, Italy's debt-to-GDP ratio in 2003 was 97\%, while France's was 53\% and Germany's 38\% (OECD, 2005), implying substantial differences in debt servicing burdens across these four euro area countries. From 1999 to 2001, average bid-ask spreads for German bonds were 2.49 basis points (bp) with quotes coming from 16 different dealers per bond, while average bid-ask spreads for Italian bonds were $4.66 \mathrm{bp}$ with quotes from an average of 6.5 dealers per bond, suggesting possibly important differences in the liquidity of bonds of different EMU countries (Jankowitsch et al., 2006).

We propose two types of tests for bond market integration in these four countries. The first test looks at the unconditional correlations between yields of different countries. We find strong evidence of convergence in the levels and comovement of yields across countries even for daily changes in yields that might be expected to be substantially affected by idiosyncratic shocks and differential liquidity characteristics. Although the current financial market turmoil in 2007-08 has increased spreads and reduced comovement across euro area yields, due perhaps to differences in risk and liquidity across countries, we show that these spreads 
are still very small compared to the period before EMU. Moreover, using the UK as a "control" country for comparison, we show that this convergence in levels and comovement is unique to the euro area members, suggesting that this convergence is due to EMU rather than to a more general global tendency toward convergence across all developed countries.

Our second type of test looks at the conditional, as opposed to the unconditional, behavior of bond yields in the euro area countries. That is, conditional on the announcement of a given piece of economic news, do yields in France, Germany, Italy, and Spain react similarly? In a unified bond market, bonds of different countries (at the same maturity) should respond similarly to the same impulse whether or not there are constant differences in risk or liquidity spreads and whether or not there is bond-specific and country-specific noise. As conditioning variables, we use major macroeconomic announcements in the four euro area countries, the aggregate euro area, the UK, and the US. We find that there has been a remarkable convergence and reduction over time in the heterogeneity of euro area yield responses to these macroeconomic announcements. This convergence process seems to have been strongest just before and after monetary union in 1999, underlining the likely role of monetary union in this process.

Having established evidence in favor of bond market unification, we turn to the question of long-run inflation expectations in the euro-area countries. One desired outcome at the time when EMU was conceived was having countries with less well-anchored expectations, and therefore more volatile financial markets, benefit from a more credible monetary policymaking framework. Following Gürkaynak, Sack, and Swanson (2005), we therefore ask whether the volatility of very far-ahead forward interest rates has decreased over time. Intuitively, if long-run inflation expectations in a country are well anchored, then its farahead forward interest rates should be more stable than if those long-run inflation expectations are not well anchored. We show that the volatility of far-ahead forward rates has decreased significantly in Italy and Spain, to the level of Germany and France (which itself has decreased somewhat), suggesting that the anchoring of long-run inflation expectations in the former two countries has converged to about the same level as the latter two.

EMU has been a multi-faceted process with different stages, including exchange rate management, criteria for fiscal policy, and finally monetary union with a single monetary policy. It is therefore difficult to gauge which of these elements has been the most important 
one in driving bond market convergence in Europe. We nevertheless try to shed light on this question by extending our analysis to the more limited data that we have available for Belgium, Finland, Denmark, and Sweden. The first two of these countries are members of EMU and the last two are not, but Denmark strongly and credibly pegs its currency to the euro while Sweden allows its currency to float freely. This extension not only confirms the robustness of our results for the four largest EMU members, it also helps to shed light on the mechanisms of the convergence process by showing that Danish yields are now indistinguishable from EMU member countries' yields, while Swedish yields continue to behave very differently.

Our analysis of convergence of bond yields and long-run inflation expectations in the euro area draws upon several strands of the literature. Baele et al. (2004) is an early contribution that studied the convergence in the government bond markets of EMU member countries with lower (monthly) frequency data; our tests for bond market integration at daily frequency thus represents a much stricter test for unification. Since Baele et al., a number of studies have found significant differences in yield spreads across euro area countries even after EMU due either to differences in credit risk (Codogno et al. 2003, Manganelli and Wolswijk 2007) or liquidity (Gómez-Puig 2006, Jankowitsch et al. 2006, Favero et al. 2008). ${ }^{1}$ Relative to these studies, our contribution is to look at high-frequency, daily bond market data over a long time series to investigate the extent of bond market convergence in EMU countries; such a comprehensive study using daily data has not been carried out previously because daily yield curves for some of our countries are not generally available.

Our paper also studies the convergence and anchoring of long-term inflation expectations in the euro area by analyzing the behavior of far-ahead forward interest rates. In this respect, we build on the work of Gürkaynak, Sack, and Swanson (2005) for the US and Gürkaynak, Levin, and Swanson (2006) for the US, UK, and Sweden. Those studies find that far-ahead

\footnotetext{
${ }^{1}$ There has been a discussion whether the ECB's collateral policy leads market participants to ignore differences in national sovereign default risk. The ECB has classified assets that can be used as collateral in its regular monetary policy operations, assigning specific "valuation haircuts" to each category. These haircuts specify a percentage discount that is applied to the market price of an asset when used as collateral. The discussion focused on the fact that government bonds from all national central governments have been classified in the same category. Buiter and Sibert (2006) argued that this will effectively turn them into perfect substitutes, such that markets ignore country-specific default risk. Issing (2005), on the other hand, argued that the ECB values any asset that is taken as collateral at market values, such that a differentiation according to default risk is already incorporated. The evidence of Manganelli and Wolswijk (2007) suggests that government bond yield spreads do in fact depend on the rating of the underlying bond.
} 
forward interest rates in the US respond significantly to macroeconomic announcements, while those in the UK and Sweden (both inflation targeters) are much less responsive, suggesting a better anchoring of long-term inflation expectations in the latter two countries. Ehrmann, Fratzscher, and Rigobon (2005) show that euro area macroeconomic announcements do not have significant effects on US financial markets, while Ehrmann and Fratzscher (2005) show that the effects of US macroeconomic announcements on European financial markets have increased since the advent of EMU, which they relate to financial market learning. Goldberg and Klein (2005) study euro area interest rates in the immediate aftermath of EMU and show that their response to US inflation surprises changes over this period, which they interpret as the ECB gaining greater credibility in financial markets after its inception.

Although not directly related to our bond market analysis, there are also a few studies of how capital flows and equity market returns have converged in the euro area due to EMU (e.g. Coeurdacier and Martin. 2007, Fratzscher and Stracca 2008), and a literature on the effects of the euro area customs union on the goods market, which finds mixed evidence on convergence: for example, Canova, Ciccarelli and Ortega (2007) find that business cycles have not become more aligned in euro area countries after EMU, while Rogers (2007) finds that price dispersion across these countries has diminished. Lane (2006) contains an accessible summary of the general convergence after the EMU, in real and financial sectors and well as labor mobility.

The remainder of our paper is organized as follows. Section II describes the data, including the yields, the macroeconomic surprises as conditioning variables, and the choice of subperiods around the advent of EMU. Section III contains the results of the tests of convergence and Section IV presents evidence on the anchoring of long-term inflation expectations. Section V extends the analysis to smaller EMU and non-EMU countries and discusses possible sources of yield curve convergence. Section VI offers a general discussion of the findings and concludes. A Data Appendix provides a detailed description of all the data used in our analysis. 


\section{Data}

A detailed account of all the data used in our analysis is presented in the Data Appendix at the end of this paper, but is briefly summarized here. The basic data we employ are daily zero-coupon government bond yields for a number of European countries. We study these data both in terms of their levels, their unconditional variances and covariances, and their conditional responses to major macroeconomic announcements in Europe and the US.

\subsection{Yields}

In order to compare "apples to apples" in our analysis, we require bond yield data that are as comparable as possible across all of our countries. This requires data from a zero-coupon yield curve for each country, which removes differences in coupon rates, bond maturities, and individual bond idiosyncrasies across countries and allows for a clean comparison of yields from one country to another (see Gürkaynak, Sack, and Wright, 2007, for additional discussion).

We obtained daily zero-coupon yield curve data for Belgium, Finland, Germany, Spain, and Sweden from the Bank for International Settlements in Basel (which in turn collects these data directly from each country's central bank), daily yield curve data for the UK from the Bank of England, and daily yield curve data for Denmark from the Danmarks Nationalbank. Similar yield curve data for France and Italy for the time periods we were interested in are not available from the BIS or other sources, so we computed the yield curves for these two countries ourselves using bond market price data from Bloomberg Financial Services and the methods employed by Gürkaynak, Sack, and Wright (2007) for the US (the other yield curves in our sample are estimated using very similar methods by the central banks themselves). Because of the distribution of bond maturities available from Bloomberg, short-term (less than five-year) yields for France and Italy are reliable only beginning in 1995, while five-year and longer rates for these countries and all yields for Germany, Spain, and the UK go back to 1993. The yield curve data for Belgium, Finland, Denmark, and Sweden, which we use for robustness checks, begin in 1999.

\subsection{Macroeconomic announcements}

For our conditional analysis of bond market responses, we examine the high-frequency response of bond yields to major macroeconomic data releases in each of France, Germany, 
Italy, Spain, the euro area as a whole, the UK, and the US. However, it is not enough to use the raw macroeconomic data releases themselves as explanatory variables because financial markets are forward-looking and thus should not respond to the component of these announcements that are expected (Kuttner, 2001, confirms this hypothesis for the case of monetary policy announcements in the US). Thus, we wish to construct the unexpected or surprise component of each of our macroeconomic data releases and use these data release surprises as the conditioning variables for our bond market analysis.

We compute macroeconomic data release surprises as the realized value of the macroeconomic data release on the day of the announcement less the financial markets' expectation for that realized value. We obtained data on financial market expectations of major macroeconomic data releases from two sources: Money Market Services (MMS) and Bloomberg Financial Services (we use the median response of the respective polls as our measure of market expectations, as is standard in the literature). Details of these data are provided in the Data Appendix. Andersen et al. (2003) and others have verified that these data pass standard tests of forecast rationality and provide a reasonable measure of ex ante expectations of the data release. We verified that this is the case for our data as well.

Note that, to make our regression coefficient estimates comparable across different data releases, we normalize each series by its sample standard deviation, so that the regression coefficient on each series can be interpreted as a response per one standard deviation surprise. For example, on 21 October 1998, the German IFO index was expected to come in at 97 but the released value was 94; since the historical standard deviation of the surprise in this data release is 1.16 , we record this as a surprise of -2.58 standard deviations for that statistic on that date.

Two additional issues regarding the macroeconomic data surprises bear further discussion. One is availability, as most of the surprises for Italy and Spain in our sample are available only from the beginning of 1997 onwards, and euro area aggregate data releases are generally available only beginning in 1999. Moreover, after the introduction of the euro, national monetary aggregate data cease to exist, so only the euro area aggregate and its surprise component is available to us from that date onward. Table A-1 in the Appendix lists all of the macroeconomic data surprise series we have used and the dates for which they are available. 
The second issue is that European bond yields often react very little to euro area aggregate data releases, due to the fact that these euro area releases aggregate information that has already been made public by the individual euro area member countries. ${ }^{2}$ For this reason, we include US and UK surprises as explanatory variables in our analysis as well. This has the added benefit that these series are often available over a long history, typically for as long as our bond yield data are available. Note that using "foreign" surprises here does not create a problem for studying bond market integration. Being agnostic on why US surprises move European yields, we only assert that if one country's yields are responding to a given data surprise, others' should as well if bond markets are integrated.

\subsection{Sample periods}

A final point relates to our choice of sample and subsample periods. The decision to have a monetary union within the EU was agreed on in the Maastricht Treaty in February 1992. However, in September 1992, the ERM (Exchange Rate Mechanism) crisis led several countries to devalue their currencies and drop out of the exchange rate system. We thus begin our sample in 1993 to make sure the results are not driven by the very high volatility in the immediate aftermath of the ERM crisis, although there was still some currency volatility and uncertainty in subsequent years. In May 1998, the eligible countries for inclusion in the monetary union were announced, and on 1 January 1999 the exchange rates for the countries entering monetary union were irrevocably fixed and the euro was introduced. Our data extends through June 2008, which implies that our analysis includes about a year of the financial market turmoil in 2007-08.

Given this timeline, we use January 1993 through December 1998 as our pre-EMU sample and January 2002 through June 2008 as our post-EMU sample. We begin the latter sample in 2002 to make sure that we are not capturing effects of the initial period of evolving credibility of the ECB, as argued by Goldberg and Klein (2005).

We check these subsample choices more formally using an Andrews-Ploberger (1994) break point test to detect the precise date of structural changes in the yields of euro area countries.

\footnotetext{
${ }^{2}$ For instance, euro area inflation announcements and even German inflation announcements occur not only much later than their US counterparts, but they also contain less information as they are preceded by announcements by each German state's inflation figures. See Ehrmann and Fratzscher (2005).
} 
For this purpose, we regress the yield of each country on the corresponding German yield and a constant - a test to which we will return to in more detail in section 3 . Table 1 shows that the date for the structural breaks occurs before 1 January 1999, usually in 1996 or 1997 , suggesting that markets anticipated the beginning of monetary union well ahead of time. The similarity in break points across countries and yields underlines the similarities in yield changes in euro area countries. Instead of taking 1 January 1999 as the end of the pre- EMU period, we therefore could also have taken an earlier break point. However, our preferred data is 1 January 1999 as this formally meant the introduction of the euro. Note that by not choosing an earlier break point, we bias our results against our hypotheses. Since we possibly include data points where bond markets had already converged, we should find weaker evidence for bond market integration in our comparisons of the pre- and post-EMU periods. Moreover, we stress that our results are insensitive to variations in the beginning and end dates of the two subsamples. In particular, starting the pre-EMU sample in 1994 or choosing an earlier start date for the post-EMU sample does not change our conclusions below.

\section{Convergence of Yields}

We begin by investigating the degree to which yields of different maturities have converged across our four large euro area countries, France, Germany, Italy, and Spain, countries for which we have a long time series of daily yields. Given that "a high degree of sustainable convergence" was a prerequisite for entry into the monetary union, finding some degree of convergence in yields before the ECB came into existence is to be expected. Our interest is in the timing and the extent of this convergence. We first study the yields across countries unconditionally and then look at the conditional correlations, using major macroeconomic data release surprises as the conditioning variables.

\subsection{Unconditional results}

To study whether and when the government bond markets in Germany, France, Italy, and Spain integrated with EMU, we focus on the daily behavior of bond yields in these four countries. The advantage of using such high-frequency data for our analysis is that it sets a higher standard for bond market convergence: at lower frequencies, it is more likely that some degree of cross-country arbitrage will reduce interest rate differentials across those countries and make those bond markets appear more similar. That is, finding convergence in 
financial markets using monthly data is more likely than finding it in daily data. Our results therefore extend those in the literature by studying higher-frequency data as well as an extended sample period. ${ }^{3}$

The evolution of daily yield curves for each of our four euro area countries is summarized in Figure 1, the central figure of this sub-section. The top panel of the figure depicts the twoyear bond yields at daily frequency. At the beginning of the sample period, the German twoyear yields are the lowest, with the French yields slightly above them. The Spanish and Italian two-year yields are five to six percentage points higher than the other two. The most striking feature of the graph is the speed and extent of the convergence of yields. The French and German yields had become identical by 1997 and the Spanish and Italian ones joined them by 1999. The lines for the four countries are indistinguishable from then on.

This is striking precisely because we are using daily data. There is not a single day after 1999 on which the two-year yield on government notes was noticeably different in one of the countries compared to the others. That is, the short term bond markets in these countries were unified to the extent that any deviations across countries appear to have been arbitraged away on a daily basis. Note, importantly, that convergence had taken place even before monetary union had actually taken place. That is, the expectation of unification unified the sovereign bond markets, which was also suggested by the results of the structural break point test discussed in the previous section.

To ensure that this convergence is due to EMU and is not an artifact of broader convergence in the yields of industrialized European countries, Figure 1 also includes the two-year yield from the UK, an EU member that is not a member of the euro area. The UK two-year yield clearly stands out in the figure, suggesting that convergence in rates did indeed happen because of the monetary union and not because of other global or regional factors that were leading to convergence across developed countries' financial markets more generally.

The middle panel of Figure 1 repeats the analysis using five-year yields. We have data on five-year yields for all of our countries going back farther, to 1993, but the results are very much the same as for two-year yields. Finally, the bottom panel of the figure depicts ten-year

\footnotetext{
${ }^{3}$ While they focus, as all other studies, on monthly data, Codogno et al. (2003) also include a section that studies one year of daily data.
} 
yields, which shows that there is slightly more variation across countries in long-term interest rates - in particular, the Italian ten-year yield has been a touch higher than the others in the recent past — but this difference is tiny compared to the differences before 1999 .

We present three kinds of statistical measures to quantify the extent of the convergence that is so visually striking in Figure 1. First, we look at the raw correlations of yields of the same maturity between different countries for the pre-EMU (1993-1998) and post-EMU (20022008) samples. Second, we show regression results for each country's yields regressed on German yields of the same maturity in each of the two sample periods. (We pick German yields as a benchmark because Germany and the Deutsche mark had functioned as the anchor during the run up to monetary union.) Third, we provide evidence from principal component analysis.

The results of the first two tests are reported in Tables 2 and 3. The correlation analysis confirms the visual impression and earlier results for lower frequency data in that the correlations between the yields of France, Germany, Italy, and Spain have increased significantly after EMU - in fact, almost all of these are .99-while the correlations of the yields of these countries with those of the UK have decreased. ${ }^{4,5}$ The $R^{2}$ statistics of the regression of each country's yields on German yields in Table 3 reinforce the raw correlations. Interestingly, the proportion of the variance that these simple regressions can explain appears to be even larger than those reported in Baele et al. (2004), especially for the shorter maturities, suggesting that convergence has strengthened over the most recent years covered in our sample. This is particularly striking given the fact that we analyze daily frequency data, which, as mentioned above, one would expect to show less comovement than data at lower frequencies. The slope coefficients in Table 3, which were quite far from unity pre-EMU, have become economically indistinguishable from unity across the four countries after EMU, while the coefficients in the regressions involving the UK have continued to have

\footnotetext{
${ }^{4}$ Throughout the paper, we study unconditional relationships in levels and conditional ones in changes. This is to make the results comparable to the corresponding literature: for example, level/slope/curvature decompositions of the yield curve (which we study in Table 4, below) always refer to yields in levels while event study regressions (which we study in Table 5) look at changes in yields in response to news. Our conclusions regarding bond yield convergence would be broadly similar if we presented the unconditional analysis in changes as well. Those results are not presented here in the interest of space, but are available from the authors upon request; some sense of them can also be gleaned from Table 5.

${ }^{5}$ Almost all of the changes in correlation coefficients across samples are statistically significant because with daily data we have very large numbers of observations in each sample, leading to very precise estimates. Note that the correlation coefficients are estimated over the sample for which data exists in all countries, effectively making the early sample for the two-year yield the 1995-98 period.
} 
slopes of varying magnitudes. ${ }^{6}$ Consistent with the convergence hypothesis, the constants in the regressions have also shrunk towards zero from the pre-EMU to the post-EMU sample.

Another way to think about bond market unification is that it implies there will be a single latent factor that underlies yields of the same maturities across all the different countries' markets. We explore this implication using principal components analysis. Let $X$ denote the $T \times 4$ matrix with rows corresponding to days and columns corresponding yields of the same maturity (2, 5 and 10 year yields) in different countries' sovereign bond markets. $X$ can be written as:

$$
X=F \Lambda+\eta
$$

where $F$ is a $T \times k$ matrix of unobserved factors (with $k<4$ ), $\Lambda$ is a $k \times 4$ matrix of factor loadings, and $\eta$ is a $T \times 4$ matrix of white noise disturbances. The hypothesis that sovereign bond markets are integrated is a statement that there exists a $T \times 1$ vector $F$ and constants $\lambda_{i}$, $i=1, \ldots, k$, such that the matrix $X$ is described by $F \times\left[\lambda_{1}, \ldots, \lambda_{k}\right]$ up to white noise.

In Table 4, we report the percentage of total variation of the data that is explained by the first two principal components. The factor loadings show that the first factor loads evenly on all countries (the common factor) while the second factor differentiates Italy and Spain from France and Germany. In the pre-EMU period, the second factor explains a non-negligible part of the total variation in all maturities, whereas in the post-EMU period the first, common factor explains essentially all of the variation. That is, the factor analysis implies that after EMU there is a single latent factor-in effect, a euro area-wide factor - that describes the behavior of yields in all of these countries, suggesting that since monetary union bond markets across the four countries have become completely integrated.

All together, the results in this section show, visually and statistically, a remarkable convergence in bond yields of the four largest euro area countries around the time of the monetary union. We next move from the unconditional results to the conditional ones and ask how the responses of the yields of different euro area countries to data surprises have changed from before monetary union to after.

\footnotetext{
${ }^{6}$ Statistically, the slope coefficients are not quite unity as with daily data we estimate these with a very high degree of precision. Thus .99 , while economically not different from unity, remains statistically different from it.
} 


\subsection{Conditional results}

Our finding of unconditional convergence in bond yields above could come about in two different ways. First, bond markets may have reacted similarly to shocks during both the preEMU and post-EMU periods, but country-specific idiosyncratic shocks were much more important in the pre-EMU period, and common shocks more important after EMU. The diminishing importance of country-specific idiosyncratic shocks would then show up in the bond markets as convergence. Alternatively, common shocks may have been equally important in both the pre-EMU and post-EMU periods, but bond markets in each country may have reacted differently to these common fundamental shocks before EMU and more similarly after EMU. To investigate more fully the type of convergence that has taken place, we now analyze the conditional movements in bond yields in our four countries in response to major macroeconomic data releases.

Our regression specification for this analysis is

$$
\Delta y_{t}^{i, j}=\alpha^{i, j}+\sum_{k=1}^{K} \sum_{l=1}^{L_{k}} \beta_{l, k}^{i, j} \text { Surprise }_{l, k, t}+\varepsilon_{t}^{i, j}
$$

where $\Delta y_{t}^{i, j}$ denotes the daily change in the yield of maturity $j(j \in\{2,5,10\}$ years) of country $i(i \in\{$ France, Germany, Italy, Spain $\})$ on date $t$. We have surprise data from six countries and the euro area ( $k \in\{$ France, Germany, Italy, Spain, UK, US, euro area $\})$ and there are $L_{k}$ data series used from each of these, indexed by $l(l \in\{\mathrm{CPI}$, Unemployment, etc.\}). Due to data availability, we have more data surprises for the US than for any other country, but this does not present any particular difficulties because US macroeconomic data release are known to significantly affect financial markets in Europe as well as in the US (Andersen et al. 2007, Ehrmann and Fratzscher, 2005). Note that, due to data availability, not all of the data releases we consider were present in both the pre- and post-EMU samples.

Regression results from specifications using the complete set of all 37 of our data release surprises are not presented to save space and because most of those coefficients are not statistically significant anyway, especially for European macro data announcements in the pre-EMU period. Therefore, we report in Table 5 regression results from a more parsimonious specification that uses a much smaller subset of the available macroeconomic 
announcements, in particular, the most important US data releases (as suggested by Fleming and Remolona, 1999), the CPI inflation releases for each of the four euro area countries, and the M3 growth rates for Germany and the euro area as a whole (which may be expected to matter because of the emphasis on monetary aggregate growth rates first by the Bundesbank and then by the ECB).

The most important point of Table 5 is that before EMU there were no cases where all countries' yields responded significantly to the same data release. One could use this as a definition of market segmentation-prices are not moved by the same common fundamentals. ${ }^{7}$ By contrast, after EMU yields of euro area countries react in a much less heterogeneous manner to macroeconomic announcements. In Table 5, this is especially the case for the major releases of US ISM, US nonfarm payrolls and the German CPI and IFO index. The direction and size of the responses to these releases are as one might expect: surprises in all of these procyclical releases lead to higher yields in all countries. Moreover, the sizes of the responses are similar to what was found in the US for comparable releases by Gürkaynak, Sack and Swanson (2005).

The results in Table 5 are summarized graphically in Figures 2 and 3, which depict the timevarying responses of yields to nine of these potentially relevant macro surprises, using a rolling estimation of 4-year windows. Figure 2 plots the raw response coefficients over time, but since we are primarily interested in the heterogeneity in the responses of yields across countries, Figure 3 summarizes the results in Figure 2 by plotting the cross-sectional standard deviation of the response coefficients $\beta^{i}$ across countries at each point in time (that is, when the coefficients $\beta^{i}$ differ greatly across our four countries, then the cross-sectional standard deviation plotted in Figure 3 is higher). This figure allows us to visualize the evolution over time of the cross-country heterogeneity in yield responses with a single aggregate measure.

Similar to the results in Table 5, there is clear evidence in Figure 3 of a convergence in the response patterns of yields in our four euro area countries to these macroeconomic surprises.

\footnotetext{
${ }^{7}$ It is worthwhile repeating that the inference we want to draw at this point is not about the direction of the effect that a given release exerts on financial markets. Positive US surprises, for example, may increase or decrease yields in other countries, and we do not take a stand on why a given release has a particular sign. Our test is simply that, if an announcement has an effect on the yields of one country, it should have an effect in the same direction and of a similar magnitude on the yields of other countries if bond markets are unified.
} 
Moreover, this convergence process seems to have been strongest just before and after monetary union in 1999, underlining the likely role of monetary union in this process.

There is also some evidence in Figure 2 of trends in the effects of macro surprises over time. Some macro surprises, such as US nonfarm payroll employment, and to some extent the German IFO confidence index and the US ISM survey, may have started to exert a generally larger impact on bond markets over time. By contrast, other macro variables, such as most domestic inflation announcements, have been exerting a smaller effect on bond markets over time. This finding is sensible, as it suggests that with a common monetary policy and an integrated euro area bond market what matters for each country's bond market is not the individual country's rate of inflation, but that of the euro area as a whole and that individual country's data matter to the extent they affect the euro area aggregate.

To summarize, the evidence in Table 5 and Figures 2 and 3 suggests that the unconditional convergence in euro area bond yields documented in the previous section cannot be attributed simply to a reduction in the importance of idiosyncratic, country-specific shocks in those countries over time. Instead, there appears to have been a remarkable convergence in the response of euro area yields even conditioning on individual macroeconomic data releases. The timing of this convergence also suggests that monetary union did lead to convergence and unification in euro area bond markets, and that such a unified market was not present before EMU. This convergence appears to have taken place both in an unconditional and a conditional sense, where we have used major macroeconomic announcements as conditioning variables.

\section{Anchoring of Long-term Inflation Expectations}

We now investigate the anchoring of long-run inflation expectations in the euro area and the benefits that some of those countries might have realized from entering the monetary union. In previous work, Gürkaynak, Sack, and Swanson (GSS, 2005) and Gürkaynak, Levin, and Swanson (GLS, 2006) used long-term bond yields to investigate the anchoring of inflation expectations in the US, UK, and Sweden, and we build on their analysis here. In particular, in standard macroeconomic models in which the steady-state inflation objective of the central bank is constant over time and known by all economic agents, short-term interest rates should return within a reasonable time to steady state after a macroeconomic shock, so that these 
shocks have only transitory effects on the future path of interest rates. As a result, one would expect only a limited response of long-term interest rates to these disturbances. Putting this prediction in terms of forward rates, one would expect virtually no reaction of far-ahead forward interest rates to such shocks.

\subsection{Far-ahead forward interest rates}

Conceptually, it is perhaps easiest to think about the term structure implications of shocks in terms of forward rates rather than yields. For a bond with a maturity of $m$ years, the yield $r_{t}^{(m)}$ represents the rate of return that an investor requires to lend money today in return for a single payment $m$ years in the future (for the case of a zero-coupon bond). By comparison, the $k$-year-ahead one-year forward rate $f_{t}^{(k)}$ represents the rate of return from period $t+k$ to period $t+k+1$ that the same investor would require to commit at time $t$ to a one-year loan beginning at time $t+k$ and maturing at time $t+k+1$. The link between these concepts is simple: an $m$-year zero-coupon security can be viewed as a sequence of one-year forward agreements over the next $m$ years. The $k$-year-ahead one-year forward rate $f_{t}^{(k)}$ can thus be obtained from the yield curve by the simple definition: ${ }^{8}$

$$
1+f_{t}^{(k)}=\frac{\left(1+r_{t}^{(k+1)}\right)^{k+1}}{\left(1+r_{t}^{(k)}\right)^{k}}
$$

Intuitively, the difference between the nine and ten year yields depend on the expected yield for the tenth year and this can be recovered through the formula above.

The advantage of using forward rates rather than yields is that they serve as a proxy for expectations of future values of the short-term interest rate, up to a (possibly time-varying) term premium. If the term premium moves relatively slowly over time, then the discussion in the previous section (and the analysis in GSS and GLS) suggests that far-ahead forward interest rates should be unresponsive to news if long-term inflation expectations are well anchored. ${ }^{9}$

\footnotetext{
${ }^{8}$ If we observed zero-coupon yields directly, computing forward rates would be as simple as this. In practice, however, most government bonds make regular coupon payments and thus the size and timing of the coupons must be accounted for to translate observed yields into the implied zero-coupon yield curve. Note also that our yield curve data is all quoted on a continuously-compounded basis, which implies that our forward rate data is given by $f_{t}^{(k)}=(k+1) r_{t}^{(k+1)}-k r_{t}^{(k)}$ rather than the equation in the text, which is for annually-compounded yields.

${ }^{9}$ GSS and GLS present evidence that suggests that the risk premium does not vary substantially at daily frequencies in their data sets. Several papers in the macro-finance literature, such as Cochrane and Piazzesi
} 
If EMU improved the anchoring of long-term inflation expectations in our four euro area countries, this should be reflected in a reduced volatility of far-ahead forward interest rates and their responsiveness to shocks. While it is possible to investigate this implication both unconditionally and conditional on data surprises as in the previous section, here we only present findings from the unconditional analysis. This is because anchoring is tested by the absence of systematic response of far-ahead forward rates to data surprises, and since there is very little systematic response to anything in the pre-EMU period (Table 5), the conditional analysis does not add more information to the unconditional one regarding the anchoring question. $^{10}$

Given our interest in studying long-run inflation expectations, we focus our analysis on the longest maturity for which we have high-quality bond yield data across all of our countries. The exceptional depth and liquidity of the markets for government securities around the tenyear horizon suggests focusing on the one-year forward rate from nine to ten years ahead (i.e., the one-year forward rate ending in ten years). As shown in GSS and GLS, this horizon is long enough for standard macroeconomic models to essentially return to steady state, so that any movements in forward interest rates at these horizons are very difficult to attribute to transitory responses of the economy to a shock.

\subsection{The behavior of far-ahead forward interest rates in EMU countries}

Studying the simple summary statistics for far-ahead forward interest rates in France, Germany, Italy, and Spain turns out to be very instructive. Table 6 reports the means and standard deviations of the forward rates for each of these countries in the pre- and post-EMU periods. While the fall in the mean values of these rates is impressive for Italy and Spain, our primary interest here is in their variability. Remarkably, the variability of the forward rates in Italy and Spain is twice as large as those in France and Germany in the pre-EMU period, while the forward rate variance in all four countries are essentially identical after EMU.

(2005) and Piazzesi and Swanson (2008), have also suggested or found evidence that risk premia move primarily at business cycle frequencies.

${ }^{10}$ That is, while the conditional evidence points to anchored expectations in the post-EMU period, it does not show systematic responses of far-head forward rates in the pre-EMU period either; thus, it does not help differentiate between the two periods. The lack of systematic responses in the pre-EMU period may be due to the fact that in segmented markets, participants paid attention to different releases of information which may not be captured in our list of variables. The results of the conditional exercise are available from the authors upon request. 
While the forward rates of France and Germany become considerably better anchored (less variable) after EMU, ${ }^{11}$ the improvement in the stability of forward rates in Italy and Spain after EMU is even more dramatic. Thus, it seems that the latter two countries benefited substantially from joining the euro area not only in that the levels of their forward rates declined, but also in that the variability of those rates has fallen substantially and converged to that of France and Germany.

Another way of making this point is through factor analysis. When yields of different maturities are decomposed into factors, it is standard to find a "level" factor that moves yields of all maturities in the same direction and by about as much, and a "slope" factor that rotates the yield curve. We ask how much of the variability in 2-10 year yields is explained by each of these factors in the four countries both before and after EMU. Table 7 presents the results.

In the pre-EMU period, both the "level" and "slope" factors affected the yields of France and Germany, with a dominant weight on the level factor (the first factor in Table 7), similar to the US and UK (not reported). In contrast, Italy and Spain in this period had only one factor - the level factor-influencing their yields, as this factor explains essentially all of the variation in yields of all maturities. That is, almost all movements in the yield curve that changed short-term interest rates were typically seen as level shifts, or permanent changes, affecting the long end of the yield curve by about as much as the short end. Thus, this evidence suggests a very low level of anchoring of long-term interest rates in Italy and Spain in the pre-EMU period.

After EMU, however, the weights on the level and slope factors for Italy and Spain begin to look much more like those of France and Germany. Moreover, the slope factors (the second factors in Table 7) in all four countries appear to have become more important after the advent of EMU. Thus, not only did the variability of far-ahead forward rates decrease significantly in Italy and Spain after the monetary union, they also became less closely tied to short-term rates, implying a lesser degree of pass-through from the short-term interest rate outlook to expectations about interest rates in the distant future. By this metric, it appears that Italy and Spain obtained a much better anchoring of long-term interest rates and inflation expectations as a result of entering the monetary union. Not only does EMU appear to have

\footnotetext{
${ }^{11}$ For German rates, this observation is also made in European Central Bank (2004).
} 
brought about a convergence in bond markets, it has done so in a way that reflects central bank credibility in member countries.

\section{Extensions and Discussion}

In addition to France, Germany, Italy, Spain, and the UK, we were able to obtain daily yield curve data for Belgium, Finland, Denmark, and Sweden for a subset of our sample period. Belgium and Finland have been euro area members since the birth of the euro on 1 January 1999, while Denmark and Sweden have been European Union members but have not joined (and are not currently scheduled to join) the euro area. Denmark strongly and credibly pegs its currency to the euro and its monetary policy to the ECB, while Sweden allows its currency to float freely and pursues an independent monetary policy.

These four additional countries allow us to check the robustness of our basic results and to better identify the sources of bond yield convergence in the EMU. Belgium and Finland allow us to check whether smaller EMU members benefited to the same extent as the largest ones. Denmark and Sweden, because of their different exchange rate and monetary policies, provide two additional "control" countries that help to shed light on which aspects of EMU have been the most important for bond yield convergence in the euro area. ${ }^{12}$

\subsection{Results for smaller EMU and non-EMU countries}

The data we have for Belgium, Finland, Denmark, and Sweden do not extend all the way back to the early 1990s, so we cannot study the entire process of EMU convergence for these four countries. However, we do have data for all of these countries since at least 2003, so we can observe and compare to what extent convergence and bond market integration have actually taken place. Figure 4 plots the time series of yields across these four countries together with those of Germany as a benchmark for comparison. The convergence of the Belgian, Finnish, and Danish yields to those of Germany is striking. So is the lack of convergence of Sweden.

\footnotetext{
${ }^{12}$ The UK served as a control country in our analysis above, but the UK is a large country that has other systematic differences from continental Europe, such as closer trade ties to the US and more laissez-faire labor market policies. Denmark and Sweden are more similar to continental Europe and are very similar to each other, and thus may provide a better set of controls for comparison.
} 
Note that Swedish yields at the ten year maturity are quite close to those of the EMU members and Denmark. Sweden has followed a very successful inflation targeting monetary policy for more than a decade, and Gürkaynak, Levin, and Swanson (2006) present evidence that the Swedish Riksbank's inflation targeting framework has anchored long-run inflation expectations in that country quite well. It is thus not too surprising that the euro area and Sweden have similar long-term bond yields, since both have successfully anchored long-run inflation expectations at similar levels. Instead, the differences between Sweden and the euro area countries are most apparent at shorter maturities. Figure 1 shows that this same observation also holds true for UK yields (as discussed in GLS, the UK is another successful inflation targeting country).

Table 8 quantifies and corroborates the observations above by regressing bond yields for each of these four smaller European countries on German yields of the same maturity. As one would expect from Figure 4, regressions of Belgian, Finnish, and Danish yields on those of Germany give estimated constants close to zero, slope coefficients near unity, and very high $R^{2}$ statistics, while none of these is true for Swedish yields. We do not report results for the complete battery of tests run in the previous section in the interest of space, but these results are very similar and further corroborate the evidence in Figure 4 and Table $8 .{ }^{13}$ Clearly, bond yield convergence was a general phenomenon in the euro area that applied to smaller as well as larger EMU members, and even to Denmark, a country that is not officially part of EMU.

\subsection{Sources of convergence: monetary policy, exchange rate peg, or fiscal policy?}

The Maastricht Treaty laid the foundation for monetary union in 1992, but it also mandated a loose exchange rate peg and required basic convergence of fiscal policies in order for countries to be eligible to enter into the union. To what extent, then, is the convergence in long-term bond yields that we see in Figures 1 and 4 a result of monetary union, the loose exchange rate peg leading up to the union, or a reduction in default risk through fiscal policy convergence?

The pre-EMU exchange rate peg is probably unable by itself to explain the bond yield convergence in Figures 1 and 4. Although the Maastricht Treaty originally required countries to keep their exchange rates within a band of plus or minus $2 \frac{1 / 4}{4}$ of each other, the ERM

\footnotetext{
${ }^{13}$ These results are available from the authors upon request.
} 
crisis in September 1992 led to this aspect of the treaty being revised to allow fluctuations of plus or minus $15 \%$, a much wider band. Because of the tremendous width of this band, exchange rate risk for EMU countries remained quite high in the up-run to EMU. Moreover, the timing of bond yield convergence in Figure 1 does not seem consistent with the 1990s exchange rate peg playing a major role: for example, from the onset of the ERM crisis to the loosening of the peg on 2 August 1993, bond yield spreads across countries didn't widen, counter to what one would expect if exchange rate risk were the dominant factor. Moreover, from August 1993 through the end of 1998, the exchange rate band was unchanged at $\pm 15 \%$, yet cross-country yield spreads both rose and fell substantially over this period, again suggesting that the pre-EMU exchange rate peg was not the main driving force.

This is not to say that exchange rate policy is unimportant. Denmark has not adopted the euro per se and is not a member of EMU, but its exchange rate and monetary policy are pegged so tightly to the euro and to the ECB that the exchange rate risk between the two currencies has been minimal. As we saw in Figure 4, Denmark's bonds display a very high degree of integration with those of the euro area, while Sweden — which has many similarities to Denmark but a flexible exchange rate and independent monetary policy-does not display nearly the same degree of bond market integration with the EMU countries. The point above is that the loose, pre-EMU exchange rate peg, with bands of $\pm 15 \%$, seems to account for little of the convergence in long-term bond yields in Figure 1; instead, financial market anticipation of the (post-EMU) unification of the currency-with the associated complete elimination of exchange rate risk - and common monetary policy appears to have been much more important.

To what extent could convergence in fiscal policy — as required by the Maastricht Treaty and the Stability and Growth Pact - and a corresponding reduction in credit risk explain the convergence of euro area long-term bond yields? Denmark, Sweden, and the UK all met the Stability and Growth Pact criteria for fiscal discipline throughout our sample, in fact behaving better than some EMU member countries in this respect. Yet bond yields in Sweden and the UK display relatively little convergence toward those of the euro area. This suggests that greater fiscal restraint on the part of Italy and Spain was not a major factor in bringing those countries' yields into line with those of France and Germany. 
Additional evidence that pre-EMU fiscal policy was not a major factor behind bond yield spreads is provided in Figure 5, which depicts long-term bond yields for the three largest US states: California, New York, and Texas. ${ }^{14}$ Like the EMU nations, these three states share a common currency and a unified monetary policy. Unlike the euro area, there is no equivalent of the Maastricht criteria for US states - their fiscal policies are restricted only by political and market forces. Indeed, the relative fiscal positions of these three states has varied widely in recent years, along with the booms and busts in the technology, finance, and oil industries. Yet the comovement of US state bond yields in Figure 5 is remarkably similar to the comovement of euro area bond yields since EMU in Figure 1 (note the difference in the scale of the vertical axes). The average daily spread between the lowest and highest yield in Figure 5 is just 17 basis points, and the maximum difference 54 basis points, very similar to the values for the eurozone bonds since EMU. Moreover, in Figure 5, the ebb and flow of default risk is clearly discernible: from July 1999 through April 2001, California's fiscal position strengthened as a result of tax revenues from the technology boom of the late 1990s, and California's long-term yields averaged about 25 basis points lower than those of New York and Texas. From January 2002 through June 2004, and again more recently, California faced severe budget crises and its long-term bond yields averaged roughly 25 basis points higher than those of New York and Texas. Thus, the relatively wide swings in California's fiscal position vis-à-vis New York and Texas seem to account for no more than 50 basis points of yield premium (from -25 to $+25 \mathrm{bp}$ ) over this whole period. Translating this observation over to the euro area, it suggests that the convergence in fiscal policy required by Maastricht and the Stability and Growth Pact was probably not very important for long-term bond yield convergence in the EMU, perhaps accounting for less than 1 out of the 8percentage-point reduction in spreads in Figure 1.

Again, this should not be taken as saying that the fiscal requirements of Maastricht and the Stability and Growth Pact were unimportant for EMU. Indeed, one can imagine that EMU might not have been possible without these requirements. Our results simply suggest that the fiscal convergence criteria themselves, and any reduction in credit risk that they implied, were probably not very important for bond market convergence relative to financial markets' anticipation of the elimination of exchange rate risk and a unified, credible monetary policy.

\footnotetext{
${ }^{14}$ These data are the 10-year general obligation bond index for each state from Bloomberg Financial Services. Note that, unlike the eurozone bonds in Figure 1, these US state government bonds receive favorable tax treatment in the US, so one should not read too much into differences in the levels of yields across Figures 1 and 5. We will focus instead on comovement and yield spreads within each figure.
} 


\section{Conclusions}

We find much evidence that monetary union in Europe has effectively created a single, unified euro area bond market, despite the fact that there may be credit risks that differ across countries and liquidity characteristics that may vary from one sovereign bond to another. In fact, the ongoing financial crisis in 2007-08 demonstrates that such credit and liquidity premia can at times still affect yield spreads across euro area countries, but these spreads are still very small compared to the period before EMU. Our analysis shows that bond yield convergence in the euro area has taken place not only for the level of bond yields across countries but also for their day-to-day movements, both unconditionally and conditional on their responses to major macroeconomic announcements.

Moreover, we find evidence of convergence in the anchoring of long-term inflation expectations in the euro area, as reflected in the behavior of far-ahead forward nominal interest rates. All of the countries in our sample experienced some degree of improvement, but the gains have been the most dramatic by far for Italy and Spain, which over time have attained far-ahead forward interest rates that are now as low and as stable as those of Germany and France, a remarkable achievement.

A comparison of EMU countries to the UK, Denmark, and Sweden suggests that convergence in fiscal policy, the relatively loose exchange rate peg of the $1990 \mathrm{~s}$, or even the common currency itself were not very important for the convergence of long-term bond yields in the euro area. Instead, financial market anticipation of the adoption of a unified monetary policy and the elimination of exchange rate risk across countries seem to have been the primary factors driving bond market convergence. Denmark is particularly interesting, since it has experienced the same degree of bond market convergence as the EMU nations, despite the fact that Denmark has not adopted the euro per se, instead choosing to tightly link its currency and monetary policy to the euro and ECB. Our results are thus relevant not only for the euro area, but also for the design of common currency areas in general and for credible fixed exchange rate regimes such as those in Hong Kong and the Middle East.

Finally, in contrast to the strong evidence for convergence in financial markets, Canova et al. (2007) find a much lower degree of convergence in the real economies of the euro area. This highlights interesting issues for the conduct of monetary policy, which is transmitted to the 
national economies via financial markets in a rather homogeneous way, yet faces substantial heterogeneity with regard to the real economy. Other interesting questions are whether convergence in financial markets fosters further real convergence, and how default and liquidity risk premia in the current financial crisis will evolve once the financial turmoil is over. We leave these important questions for future research. 


\section{References}

1. Andersen, T., T. Bollerslev, F. Diebold, and C. Vega (2003), "Micro Effects of Macro Announcements: Real-Time Price Discovery in Foreign Exchange," American Economic Review 39(1), 38-62.

2. Andersen, T., T. Bollerslev, F. Diebold, and C. Vega (2007), "Real Time Price Discovery in Global Stock, Bond, and Foreign Exchange Markets," Journal of International Economics 73(2), 251-77.

3. Andrews, D.W.K. and W. Ploberger (1994), "Optimal tests when a nuisance parameter is present only under the alternative," Econometrica, 1383-414.

4. Baele, L., A. Ferrando, P. Hördahl, E. Krylova, and C. Monnet (2004), "Measuring Financial Integration in the Euro Area," ECB Occasional Paper \#14.

5. Buiter, W. and A, Sibert (2006), "How the Eurosystem's Treatment of Collateral in its Open Market Operations Weakens Fiscal Discipline in the Eurozone (and what to do about it)," in National Bank of Poland (ed.), Fiscal Policy and the Road to the Euro, Warsaw: National Bank of Poland, 29-60.

6. Canova, F., M. Ciccarelli, and E. Ortega (2007), "Similarities and Convergence in G-7 Cycles," Journal of Monetary Economics 54(3), 850-78.

7. Codogno, L., C. Favero, and A. Missale (2003), "Yield Spreads on EMU Government Bonds," Economic Policy, October, 503-532.

8. Cochrane, J. and M. Piazzesi (2005), "Bond Risk Premia," American Economic Review 95(1), 138-160.

9. Coeurdacier, N. and P. Martin (2007) "The Geography of Asset Trade and the Euro: Insiders and Outsiders," CEPR Discussion Paper \#6032.

10. Ehrmann, M. and M. Fratzscher (2005) "Equal size, equal role? Interest rate interdependence between the euro area and the United States," Economic Journal 115, 930-50.

11. Ehrmann, M., M. Fratzscher, and R. Rigobon (2005), "Stocks, bonds, money markets and exchange rates: measuring international financial transmission," NBER Working Paper \#11166, March 2005.

12. European Central Bank (2004), "The information content of euro area long-term forward interest rates," Monthly Bulletin, August, 25-26.

13. Favero, C., M. Pagano, and E.-L. von Thadden (2008), "How does Liquidity Affect Bond Yields?" Journal of Financial and Quantitative Analysis, forthcoming.

14. Fleming, M. and E. Remolona (1999), "Price Formation and Liquidity in the U.S. Treasury Market: The Response to Public Information” Journal of Finance 54(5), 190115. 
15. Fratzscher, M. and L. Stracca (2008), "The political economy under monetary union: Has the euro made a difference?" ECB Working Paper, forthcoming.

16. Goldberg, L. and M. Klein (2005), "Establishing Credibility: Evolving Perceptions of the European Central Bank,” NBER Working Paper \#11792 .

17. Gómez-Puig, M (2006), "Size Matters for Liquidity: Evidence from EMU Sovereign Yield Spreads," Economics Letters 90, 156-62.

18. Gürkaynak, R., A. Levin, and E. Swanson (2006), "Does Inflation Targeting Anchor Long-Run Inflation Expectations? Evidence from Long-Term Bond Yields in the U.S., U.K., and Sweden” CEPR Working Paper \#5808.

19. Gürkaynak, R., B. Sack, and E. Swanson (2005), "The Sensitivity of Long-Term Interest Rates to Economic News: Evidence and Implications for Macroeconomic Models" American Economic Review 95(1), 425-36.

20. Gürkaynak, R., B. Sack, and J. Wright (2007), "The U.S. Treasury Yield Curve: 1961 to the Present” Journal of Monetary Economics 54(8), 2291-2304.

21. Issing, O. (2005), "One size fits all! A single monetary policy for the euro area" Speech to the International Research Forum, available at http://www.ecb.int/press/key/date/2005/ $\mathrm{html} / \mathrm{sp} 050520$.en.html.

22. Jankowitsch, R., H. Mösenbacher, and S. Pichler (2006), "Measuring the Liquidity Impact on EMU Government Bond Prices," European Journal of Finance 12(2), 153-69.

23. Kuttner, K. (2001), "Monetary policy surprises and interest rates: evidence from the Fed funds futures market," Journal of Monetary Economics 47, 523-44.

24. Lane, P. (2006), "The Real Effects of European Monetary Union," Journal of Economic Perspectives 20, 47-66.

25. Manganelli, S. and G. Wolswijk (2007), "Market Discipline, Financial Integration and Fiscal Rules. What Drives Spreads in the Euro Area Government Bond Market?" ECB Working Paper \#745.

26. Rogers, J. (2007) "Monetary union, price level convergence, and inflation: How close is Europe to the USA?" Journal of Monetary Economics 53(3), 785-96.

27. Söderström, Ulf. (2008), "Re-Evaluating Swedish Membership in the EMU: Evidence from an Estimated Model," unpublished manuscript, Università Bocconi. 
Table 1: Andrews-Ploberger structural break test

\begin{tabular}{|c|c|c|c|c|c|c|}
\hline & \multicolumn{2}{|l|}{ France } & \multicolumn{2}{|l|}{ Italy } & \multicolumn{2}{|l|}{ Spain } \\
\hline & break point & sign. & break point & sign. & break point & sign. \\
\hline \multicolumn{7}{|l|}{ 2-year yields: } \\
\hline Constant & 1997:06:16 & $* * *$ & 1997:06:11 & $* * *$ & 1996:11:04 & $* * *$ \\
\hline German rate & 1997:07:04 & $* * *$ & 1997:08:19 & $* * *$ & $1997: 04: 25$ & $* * *$ \\
\hline \multicolumn{7}{|l|}{ 5-year yields: } \\
\hline Constant & 1996:06:10 & $* * *$ & 1996:10:02 & $* * *$ & 1996:09:19 & $* * *$ \\
\hline German rate & 1996:06:27 & $* * *$ & 1997:07:02 & $* * *$ & $1996: 11: 20$ & $* * *$ \\
\hline \multicolumn{7}{|l|}{ 10-year yields: } \\
\hline Constant & 1997:06:30 & $* * *$ & 1997:01:10 & $* * *$ & 1996:06:14 & $* * *$ \\
\hline German rate & 1996:06:10 & $* * *$ & 1996:11:04 & $* * *$ & 1996:11:07 & $* * *$ \\
\hline \multicolumn{7}{|l|}{ 9-year forward: } \\
\hline Constant & 1997:10:03 & $* * *$ & 1996:11:04 & $* * *$ & 1996:10:31 & $* * *$ \\
\hline German rate & 1997:10:02 & $* * *$ & 1996:11:12 & $* * *$ & 1996:10:31 & $* * *$ \\
\hline
\end{tabular}

Notes. Statistics show break date and p-value of test statistics of Andrews-Ploberger (1994) test for structural breaks in the mean equations, regressing countries' yields on the German yield of corresponding maturity and a constant. 
Table 2. Correlations of rates

A. Correlations of two-year yields

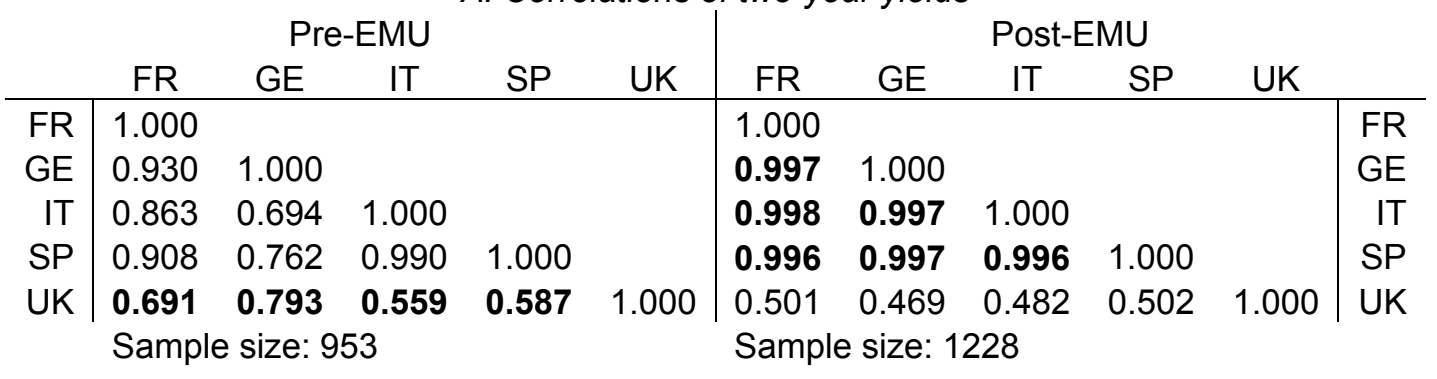

B. Correlations of five-year yields

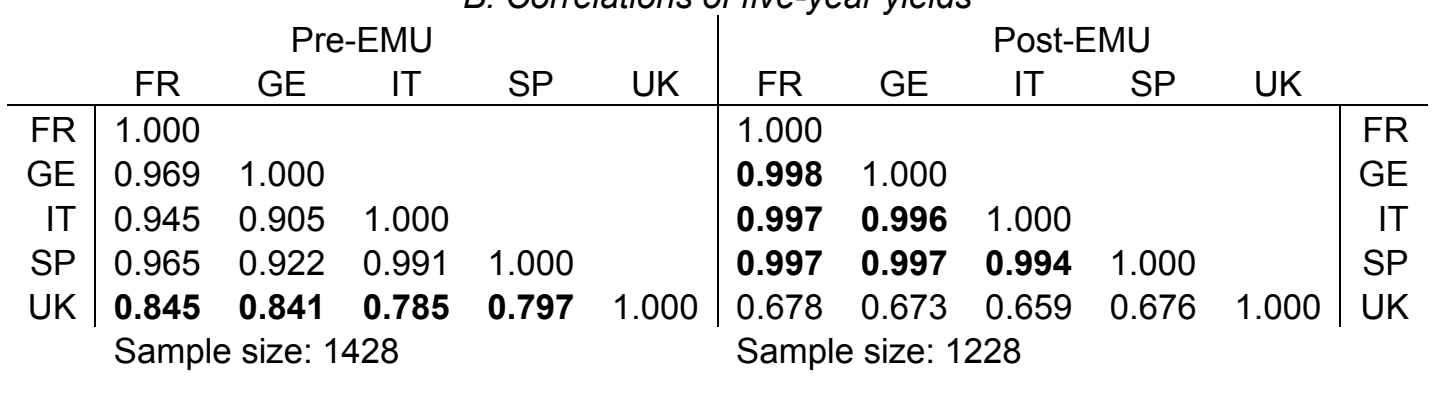

C. Correlations of ten-year yields

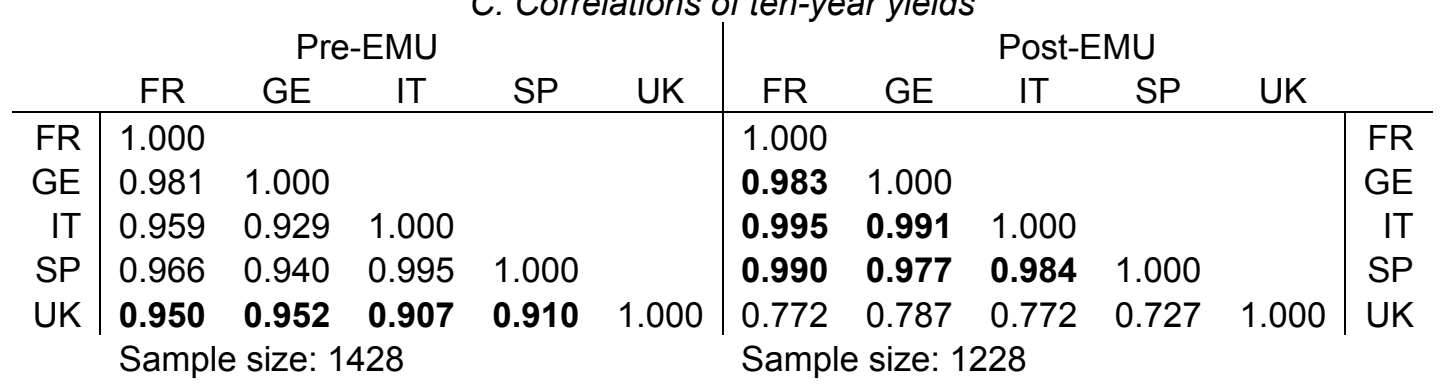

Note. Boldface entries are statistically significantly larger (at 1 percent) than their counterparts in the corresponding sample. 
Table 3. Regressions of yields on German yields

\begin{tabular}{r|llll|llll}
\multicolumn{1}{c}{} & \multicolumn{9}{c}{ A. Two-year yields } & \multicolumn{3}{c}{ Post-EMU } \\
\cline { 2 - 9 } & FR & IT & SP & UK & FR & IT & SP & UK \\
\cline { 2 - 10 } Constant & $1.425^{* * *}$ & $2.498^{* * *}$ & $2.495^{* * *}$ & $0.628^{* * *}$ & $0.971^{* * *}$ & $0.969^{* * *}$ & $0.958^{* * *}$ & $0.345^{* * *}$ \\
& $(0.022)$ & $(0.073)$ & $(0.057)$ & $(0.015)$ & $(0.002)$ & $(0.002)$ & $(0.002)$ & $(0.014)$ \\
& $-1.524^{* * *}$ & $-3.297^{* * *}$ & $-4.129^{* * *}$ & $3.992^{* * *}$ & $0.015^{* * *}$ & $0.070^{* * *}$ & $0.063^{* * *}$ & $3.338^{* * *}$ \\
Observations & $(0.089)$ & $(0.315)$ & $(0.245)$ & $(0.073)$ & $(0.006)$ & $(0.006)$ & $(0.006)$ & $(0.047)$ \\
R-squared & 953 & 953 & 953 & 953 & 1228 & 1228 & 1228 & 1228 \\
& 0.86 & 0.48 & 0.58 & 0.63 & 0.99 & 0.99 & 0.99 & 0.22
\end{tabular}

\begin{tabular}{rllll|llll}
\multicolumn{1}{c}{} & \multicolumn{9}{c}{ B. Five-year yields } & \multicolumn{3}{c}{ Post-EMU } \\
FR & FR & IT & SP & UK & FR & IT & SP & UK \\
\cline { 2 - 9 } Constant & $1.170^{* * *}$ & $2.524^{* * *}$ & $2.386^{* * *}$ & $0.829^{* * *}$ & $1.004^{* * *}$ & $1.075^{* * *}$ & $1.053^{* * *}$ & $0.459^{* * *}$ \\
& $(0.005)$ & $(0.028)$ & $(0.022)$ & $(0.014)$ & $(0.002)$ & $(0.003)$ & $(0.002)$ & $(0.009)$ \\
& $-0.856^{* * *}$ & $-5.434^{* * *}$ & $-5.398^{* * *}$ & $2.443^{* * *}$ & $-0.059^{* * *}$ & $-0.209^{* * *}$ & $-0.191^{* * *}$ & $2.922^{* * *}$ \\
Observations & $(0.027)$ & $(0.155)$ & $(0.124)$ & $(0.079)$ & $(0.006)$ & $(0.012)$ & $(0.006)$ & $(0.035)$ \\
R-squared & 1428 & 1428 & 1428 & 1428 & 1228 & 1228 & 1228 & 1228 \\
& 0.94 & 0.82 & 0.85 & 0.71 & 1.00 & 0.99 & 0.99 & 0.45
\end{tabular}

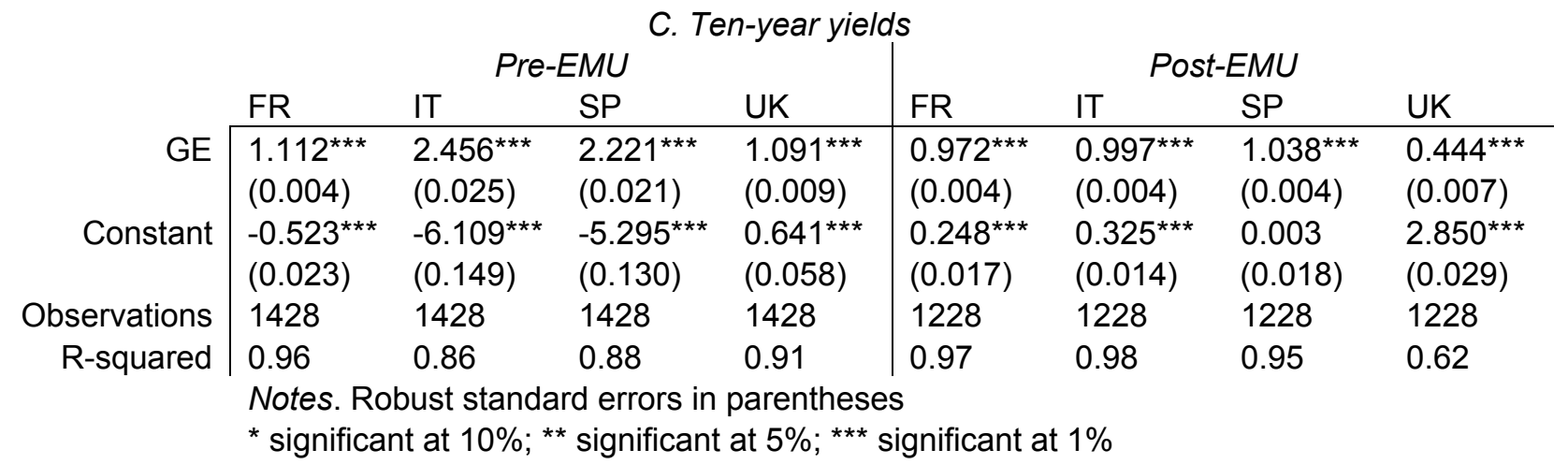


Table 4. Principal Components Analysis of Yields Across Countries

Contribution of First Principal Component

\begin{tabular}{|c|c|c|c|c|c|c|}
\hline & $\begin{array}{l}\text { Two- } \\
\text { Year } \\
\text { Yield }\end{array}$ & $\begin{array}{l}\text { Five- } \\
\text { Year } \\
\text { Yield }\end{array}$ & $\begin{array}{l}\text { Ten- } \\
\text { Year } \\
\text { Yield }\end{array}$ & $\begin{array}{l}\text { Two- } \\
\text { Year } \\
\text { Yield }\end{array}$ & $\begin{array}{c}\text { Five-Year } \\
\text { Yield }\end{array}$ & $\begin{array}{l}\text { Ten- } \\
\text { Year } \\
\text { Yield }\end{array}$ \\
\hline & \multicolumn{3}{|c|}{ Pre-EMU } & \multicolumn{3}{|c|}{ Post-EMU } \\
\hline \multirow{2}{*}{\multicolumn{7}{|c|}{$\begin{array}{l}\text { Contributions of } \\
\quad \text { First PC } \\
\text { Fis }\end{array}$}} \\
\hline & 0.895 & 0.962 & 0.971 & 0.998 & 0.997 & 0.990 \\
\hline Second PC & 0.097 & 0.031 & 0.024 & 0.001 & 0.002 & 0.006 \\
\hline \multicolumn{7}{|c|}{ Factor Loadings } \\
\hline \multicolumn{7}{|l|}{ First Factor } \\
\hline FR & 0.517 & 0.504 & 0.503 & 0.500 & 0.500 & 0.501 \\
\hline GE & 0.472 & 0.493 & 0.496 & 0.500 & 0.500 & 0.499 \\
\hline IT & 0.497 & 0.499 & 0.500 & 0.500 & 0.500 & 0.501 \\
\hline SP & 0.513 & 0.504 & 0.502 & 0.500 & 0.500 & 0.499 \\
\hline \multicolumn{7}{|l|}{ Second Factor } \\
\hline FR & 0.249 & 0.268 & 0.308 & -0.426 & -0.001 & 0.208 \\
\hline GE & 0.709 & 0.687 & 0.661 & 0.178 & -0.149 & -0.675 \\
\hline IT & -0.538 & -0.546 & -0.531 & -0.491 & 0.770 & -0.210 \\
\hline SP & -0.382 & -0.399 & -0.432 & 0.739 & -0.620 & 0.676 \\
\hline
\end{tabular}




\begin{tabular}{lcccc|cccc} 
& \multicolumn{7}{c}{ Table 5A. Response of Two-Year Yields to Surprises } \\
\cline { 2 - 9 } & \multicolumn{7}{c}{ Pre-EMU } & \multicolumn{5}{c}{ Post-EMU } \\
& FR & GE & IT & SP & FR & GE & IT & SP \\
\hline FR CPI & -0.135 & 0.730 & -0.443 & -0.310 & 0.531 & 0.489 & 0.391 & 0.648 \\
& $(0.595)$ & $(0.495)$ & $(0.785)$ & $(0.755)$ & $(0.548)$ & $(0.604)$ & $(0.565)$ & $(0.706)$ \\
GE CPI & $1.851^{* *}$ & 0.632 & 1.397 & $1.852^{*}$ & 0.478 & 0.309 & 0.526 & 0.585 \\
& $(0.770)$ & $(0.641)$ & $(1.017)$ & $(0.977)$ & $(0.395)$ & $(0.435)$ & $(0.407)$ & $(0.509)$ \\
IT CPI & -0.196 & -0.004 & 0.752 & 0.233 & -0.249 & -0.030 & 0.070 & -0.082 \\
& $(0.820)$ & $(0.682)$ & $(1.082)$ & $(1.039)$ & $(0.554)$ & $(0.610)$ & $(0.571)$ & $(0.714)$ \\
SP CPI & 0.509 & -0.808 & -0.401 & 0.278 & $1.126^{* * *}$ & 0.666 & $1.057^{* *}$ & $1.009^{*}$ \\
& $(1.074)$ & $(0.894)$ & $(1.417)$ & $(1.362)$ & $(0.434)$ & $(0.478)$ & $(0.447)$ & $(0.559)$ \\
GE IFO & 0.960 & 0.900 & 0.309 & 1.402 & $1.540^{* * *}$ & $1.958^{* * *}$ & $1.369^{* * *}$ & $1.537^{* *}$ \\
& $(0.773)$ & $(0.643)$ & $(1.019)$ & $(0.979)$ & $(0.468)$ & $(0.515)$ & $(0.482)$ & $(0.603)$ \\
GE M3 & 0.331 & 1.155 & 0.996 & 0.722 & - & - & - & - \\
& $(0.874)$ & $(0.728)$ & $(1.154)$ & $(1.109)$ & - & - & - & - \\
EA M3 & - & - & - & - & 0.209 & 0.625 & 0.183 & 0.502 \\
& - & - & - & - & $(0.464)$ & $(0.511)$ & $(0.478)$ & $(0.598)$ \\
US CPIX & 1.082 & 0.304 & -0.441 & $3.116^{* * *}$ & 0.495 & 0.942 & 0.547 & $1.224^{*}$ \\
& $(0.948)$ & $(0.789)$ & $(1.250)$ & $(1.201)$ & $(0.569)$ & $(0.626)$ & $(0.586)$ & $(0.733)$ \\
US NonFarm & & & & & & & \\
Pay. & $1.633^{* * *}$ & -0.473 & -0.627 & -0.024 & $4.416^{* * *}$ & $1.874^{* * *}$ & $4.275^{* * *}$ & $2.645^{* * *}$ \\
& $(0.566)$ & $(0.471)$ & $(0.746)$ & $(0.717)$ & $(0.599)$ & $(0.660)$ & $(0.617)$ & $(0.772)$ \\
US NAPM & 0.552 & -0.228 & 0.329 & -0.381 & $1.708^{* * *}$ & $2.021^{* * *}$ & $1.588^{* * *}$ & $1.811^{* * *}$ \\
& $(0.673)$ & $(0.560)$ & $(0.888)$ & $(0.853)$ & $(0.497)$ & $(0.547)$ & $(0.512)$ & $(0.640)$ \\
Constant & $-0.431^{*}$ & -0.331 & $-1.282^{* * *}$ & $-1.367^{* * *}$ & 0.260 & 0.133 & $0.338^{*}$ & 0.248 \\
& $(0.261)$ & $(0.218)$ & $(0.345)$ & $(0.331)$ & $(0.180)$ & $(0.198)$ & $(0.185)$ & $(0.232)$ \\
\hline Observations & 296 & 296 & 296 & 296 & 429 & 429 & 429 & 429 \\
\hline
\end{tabular}

Notes. Seemingly unrelated regression (SUR) results. Standard errors in parentheses. * significant at $10 \%$; ${ }^{*}$ significant at $5 \% ;{ }^{* * *}$ significant at $1 \%$ 


\begin{tabular}{|c|c|c|c|c|c|c|c|c|}
\hline & \multicolumn{8}{|c|}{ Table 5B. Response of Five-Year Yields to Surprises } \\
\hline & \multicolumn{4}{|c|}{ Pre-EMU } & \multicolumn{4}{|c|}{ Post-EMU } \\
\hline & FR & GE & IT & SP & FR & GE & IT & SP \\
\hline FR CPI & $\begin{array}{l}-0.697 \\
(0.617)\end{array}$ & $\begin{array}{c}0.047 \\
(0.566)\end{array}$ & $\begin{array}{l}-1.372 \\
(1.140)\end{array}$ & $\begin{array}{l}-0.520 \\
(0.873)\end{array}$ & $\begin{array}{l}0.602 \\
(0.612)\end{array}$ & $\begin{array}{l}0.573 \\
(0.624)\end{array}$ & $\begin{array}{l}0.110 \\
(0.669)\end{array}$ & $\begin{array}{l}0.768 \\
(0.729)\end{array}$ \\
\hline GE CPI & $\begin{array}{c}0.964 \\
(0.834)\end{array}$ & $\begin{array}{c}0.263 \\
(0.766)\end{array}$ & $\begin{array}{l}1.395 \\
(1.543)\end{array}$ & $\begin{array}{c}0.760 \\
(1.181)\end{array}$ & $\begin{array}{l}0.423 \\
(0.441)\end{array}$ & $\begin{array}{l}0.355 \\
(0.450)\end{array}$ & $\begin{array}{l}0.383 \\
(0.482)\end{array}$ & $\begin{array}{l}0.413 \\
(0.525)\end{array}$ \\
\hline IT CPI & $\begin{array}{l}-0.320 \\
(0.932)\end{array}$ & $\begin{array}{c}0.147 \\
(0.856)\end{array}$ & $\begin{array}{c}0.056 \\
(1.724)\end{array}$ & $\begin{array}{l}-0.247 \\
(1.320)\end{array}$ & $\begin{array}{l}-0.238 \\
(0.619)\end{array}$ & $\begin{array}{l}-0.090 \\
(0.631)\end{array}$ & $\begin{array}{l}0.139 \\
(0.676)\end{array}$ & $\begin{array}{l}-0.326 \\
(0.737)\end{array}$ \\
\hline SP CPI & $\begin{array}{c}0.153 \\
(1.222)\end{array}$ & $\begin{array}{l}-0.567 \\
(1.122)\end{array}$ & $\begin{array}{l}-0.108 \\
(2.259)\end{array}$ & $\begin{array}{l}-0.029 \\
(1.729)\end{array}$ & $\begin{array}{l}1.057^{* *} \\
(0.484)\end{array}$ & $\begin{array}{l}0.832^{*} \\
(0.494)\end{array}$ & $\begin{array}{l}0.675 \\
(0.529)\end{array}$ & $\begin{array}{l}0.970^{*} \\
(0.576)\end{array}$ \\
\hline GE IFO & $\begin{array}{c}1.358 \\
(0.868)\end{array}$ & $\begin{array}{c}0.569 \\
(0.797)\end{array}$ & $\begin{array}{c}0.720 \\
(1.605)\end{array}$ & $\begin{array}{c}0.352 \\
(1.228)\end{array}$ & $\begin{array}{l}1.359^{* * *} \\
(0.522)\end{array}$ & $\begin{array}{l}1.967^{* * *} \\
(0.533)\end{array}$ & $\begin{array}{l}1.438^{* *} \\
(0.571)\end{array}$ & $\begin{array}{l}1.420^{* *} \\
(0.622)\end{array}$ \\
\hline GE M3 & $\begin{array}{c}0.462 \\
(0.603)\end{array}$ & $\begin{array}{c}3.759^{* * *} \\
(0.554)\end{array}$ & $\begin{array}{c}0.131 \\
(1.115)\end{array}$ & $\begin{array}{c}3.061^{* * *} \\
(0.853)\end{array}$ & - & - & - & $\begin{array}{l}- \\
-\end{array}$ \\
\hline EA M3 & - & $\begin{array}{l}- \\
-\end{array}$ & $\begin{array}{l}- \\
-\end{array}$ & $\begin{array}{l}- \\
-\end{array}$ & $\begin{array}{l}0.138 \\
(0.518)\end{array}$ & $\begin{array}{l}0.782 \\
(0.529)\end{array}$ & $\begin{array}{l}0.144 \\
(0.566)\end{array}$ & $\begin{array}{l}0.933 \\
(0.617)\end{array}$ \\
\hline US CPIX & $\begin{array}{c}0.888 \\
(0.741)\end{array}$ & $\begin{array}{l}-0.518 \\
(0.681)\end{array}$ & $\begin{array}{l}-0.192 \\
(1.371)\end{array}$ & $\begin{array}{c}0.478 \\
(1.049)\end{array}$ & $\begin{array}{l}0.619 \\
(0.635)\end{array}$ & $\begin{array}{l}0.898 \\
(0.648)\end{array}$ & $\begin{array}{l}0.563 \\
(0.694)\end{array}$ & $\begin{array}{l}1.219 \\
(0.756)\end{array}$ \\
\hline $\begin{array}{l}\text { US NonFarm } \\
\text { Pay. }\end{array}$ & $\begin{array}{c}0.865 \\
(0.570)\end{array}$ & $\begin{array}{l}-0.930^{*} \\
(0.523)\end{array}$ & $\begin{array}{l}-0.767 \\
(1.054)\end{array}$ & $\begin{array}{l}-0.104 \\
(0.806)\end{array}$ & $\begin{array}{l}4.679^{* * *} \\
(0.669)\end{array}$ & $\begin{array}{l}1.910^{* * *} \\
(0.682)\end{array}$ & $\begin{array}{l}5.103^{* * *} \\
(0.731)\end{array}$ & $\begin{array}{l}2.580^{* * *} \\
(0.796)\end{array}$ \\
\hline US NAPM & $\begin{array}{c}0.852 \\
(0.675)\end{array}$ & $\begin{array}{l}-0.039 \\
(0.620)\end{array}$ & $\begin{array}{c}0.397 \\
(1.249)\end{array}$ & $\begin{array}{c}0.063 \\
(0.956)\end{array}$ & $\begin{array}{l}1.920^{* * *} \\
(0.554)\end{array}$ & $\begin{array}{l}2.010^{* * *} \\
(0.566)\end{array}$ & $\begin{array}{l}2.196^{* * *} \\
(0.606)\end{array}$ & $\begin{array}{l}1.869^{* * *} \\
(0.660)\end{array}$ \\
\hline Constant & $\begin{array}{c}-0.517^{* *} \\
(0.250) \\
\end{array}$ & $\begin{array}{r}-0.309 \\
(0.230) \\
\end{array}$ & $\begin{array}{l}0.768^{*} \\
(0.462) \\
\end{array}$ & $\begin{array}{c}-1.171^{* * *} \\
(0.354) \\
\end{array}$ & $\begin{array}{l}0.204 \\
(0.201)\end{array}$ & $\begin{array}{l}0.105 \\
(0.205)\end{array}$ & $\begin{array}{l}0.286 \\
(0.220) \\
\end{array}$ & $\begin{array}{l}0.016 \\
(0.239) \\
\end{array}$ \\
\hline Observations & 416 & 416 & 416 & 416 & 429 & 429 & 429 & 429 \\
\hline
\end{tabular}

Notes. Seemingly unrelated regression (SUR) results. Standard errors in parentheses. ${ }^{*}$ significant at $10 \%$; ${ }^{* *}$ significant at $5 \% ;{ }^{* * *}$ significant at $1 \%$ 


\begin{tabular}{lcccc|cccc} 
& \multicolumn{7}{c}{ Table 5C. Response of Ten-Year Yields to Surprises } \\
\cline { 2 - 10 } & \multicolumn{7}{c}{ Pre-EMU } & \multicolumn{5}{c}{ Post-EMU } \\
\cline { 2 - 11 } & FR & GE & IT & SP & FR & GE & IT & SP \\
\hline FR CPI & -0.455 & 0.016 & -1.893 & -0.038 & 0.571 & 0.491 & 0.320 & 0.539 \\
& $(0.588)$ & $(0.594)$ & $(1.164)$ & $(0.835)$ & $(0.550)$ & $(0.621)$ & $(0.567)$ & $(0.759)$ \\
GE CPI & 0.566 & 0.159 & 1.698 & 0.406 & 0.361 & 0.357 & 0.484 & 0.328 \\
& $(0.796)$ & $(0.804)$ & $(1.575)$ & $(1.130)$ & $(0.396)$ & $(0.447)$ & $(0.409)$ & $(0.546)$ \\
IT CPI & -0.508 & 0.219 & 0.156 & -0.733 & -0.323 & -0.011 & -0.339 & -0.419 \\
& $(0.890)$ & $(0.898)$ & $(1.761)$ & $(1.263)$ & $(0.556)$ & $(0.628)$ & $(0.574)$ & $(0.767)$ \\
SP CPI & 0.301 & -0.417 & 0.789 & -0.030 & $0.775^{*}$ & 0.734 & 0.685 & 0.467 \\
& $(1.166)$ & $(1.177)$ & $(2.307)$ & $(1.655)$ & $(0.435)$ & $(0.491)$ & $(0.449)$ & $(0.600)$ \\
GE IFO & $1.461^{*}$ & 0.530 & 0.846 & 0.737 & $0.928^{* *}$ & $1.742^{* * *}$ & $0.968^{* *}$ & 0.849 \\
& $(0.828)$ & $(0.836)$ & $(1.639)$ & $(1.176)$ & $(0.470)$ & $(0.530)$ & $(0.484)$ & $(0.648)$ \\
GE M3 & 0.380 & $4.193^{* * *}$ & -1.028 & $2.993^{* * *}$ & - & - & - & - \\
& $(0.575)$ & $(0.581)$ & $(1.139)$ & $(0.817)$ & - & - & - & - \\
EA M3 & - & - & - & - & 0.159 & 0.836 & 0.101 & 0.938 \\
& - & - & - & - & $(0.466)$ & $(0.526)$ & $(0.480)$ & $(0.642)$ \\
US CPIX & 0.677 & -0.717 & 0.140 & 1.027 & 0.677 & 0.707 & 0.734 & -0.269 \\
& $(0.708)$ & $(0.714)$ & $(1.400)$ & $(1.005)$ & $(0.571)$ & $(0.644)$ & $(0.588)$ & $(0.787)$ \\
US NonFarm & & & & & & & & \\
Pay. & 0.581 & $-0.949^{*}$ & $1.985^{*}$ & -0.312 & $3.559^{* * *}$ & $1.582^{* *}$ & $3.441^{* * *}$ & 0.477 \\
& $(0.544)$ & $(0.549)$ & $(1.076)$ & $(0.772)$ & $(0.601)$ & $(0.678)$ & $(0.620)$ & $(0.829)$ \\
US NAPM & 0.602 & -0.129 & 0.383 & -0.187 & $1.329^{* * *}$ & $1.876^{* * *}$ & $1.490^{* * *}$ & $1.598^{* *}$ \\
& $(0.645)$ & $(0.651)$ & $(1.276)$ & $(0.915)$ & $(0.498)$ & $(0.563)$ & $(0.514)$ & $(0.687)$ \\
Constant & $-0.561^{* *}$ & -0.235 & -0.636 & $-1.161^{* * *}$ & 0.076 & 0.063 & 0.073 & -0.190 \\
& $(0.239)$ & $(0.241)$ & $(0.472)$ & $(0.339)$ & $(0.181)$ & $(0.204)$ & $(0.186)$ & $(0.249)$ \\
\hline Observations & 416 & 416 & 416 & 416 & 429 & 429 & 429 & 429 \\
\hline
\end{tabular}

Notes. Seemingly unrelated regression (SUR) results. Standard errors in parentheses. * significant at $10 \%$; ** significant at $5 \% ;{ }^{* * *}$ significant at $1 \%$ 
Table 6. Summary Statistics of Far-Ahead Forward Rates

\begin{tabular}{ccc|cc|cc|cc}
\multicolumn{2}{c}{} & \multicolumn{2}{c}{ FR } & \multicolumn{2}{c}{ GE } & \multicolumn{2}{c}{ IT } & \multicolumn{2}{c}{ SP } \\
\cline { 2 - 9 } & Mean & St. Dev. & Mean & St. Dev. & Mean & St. Dev. & Mean & St. Dev. \\
Pre-EMU & 7.22 & 1.02 & 6.93 & 1.00 & 9.24 & 2.22 & 8.78 & 1.84 \\
Post-EMU & 4.89 & 0.65 & 4.55 & 0.62 & 5.18 & 0.59 & 4.87 & 0.68
\end{tabular}


Table 7. Principal Components Analysis

of Yields within Countries

Contributions of

First PC

Second PC

\begin{tabular}{cccc|cccc}
\multicolumn{4}{c|}{ Pre-EMU } & \multicolumn{4}{c}{ Post-EMU } \\
FR & GE & IT & SP & FR & GE & IT & SP \\
\hline 0.969 & 0.957 & 0.999 & 0.998 & 0.912 & 0.950 & 0.928 & 0.924 \\
0.031 & 0.043 & 0.001 & 0.002 & 0.087 & 0.050 & 0.071 & 0.074
\end{tabular}

\section{Factor Loadings}

First Factor

\begin{tabular}{ccccc|cccc} 
2 Year Yield & 0.322 & 0.307 & 0.333 & 0.333 & 0.299 & 0.309 & 0.306 & 0.303 \\
3 Year Yield & 0.330 & 0.331 & 0.333 & 0.333 & 0.324 & 0.330 & 0.326 & 0.326 \\
4 Year Yield & 0.336 & 0.339 & 0.333 & 0.333 & 0.340 & 0.339 & 0.339 & 0.339 \\
5 Year Yield & 0.338 & 0.341 & 0.334 & 0.334 & 0.348 & 0.342 & 0.345 & 0.346 \\
6 Year Yield & 0.338 & 0.340 & 0.334 & 0.334 & 0.349 & 0.342 & 0.346 & 0.346 \\
7 Year Yield & 0.337 & 0.339 & 0.334 & 0.334 & 0.345 & 0.340 & 0.343 & 0.343 \\
8 Year Yield & 0.335 & 0.337 & 0.333 & 0.333 & 0.339 & 0.337 & 0.338 & 0.338 \\
9 Year Yield & 0.333 & 0.334 & 0.333 & 0.333 & 0.331 & 0.333 & 0.331 & 0.332 \\
10 Year Yield & 0.331 & 0.332 & 0.333 & 0.333 & 0.324 & 0.329 & 0.325 & 0.325 \\
Factor & & & & & & & & \\
2 Year Yield & 0.584 & 0.695 & 0.549 & 0.426 & 0.582 & 0.638 & 0.577 & 0.585 \\
3 Year Yield & 0.428 & 0.381 & 0.456 & 0.431 & 0.421 & 0.399 & 0.419 & 0.419 \\
4 Year Yield & 0.245 & 0.172 & 0.254 & 0.323 & 0.250 & 0.210 & 0.248 & 0.247 \\
5 Year Yield & 0.072 & 0.023 & 0.068 & 0.164 & 0.088 & 0.057 & 0.089 & 0.086 \\
6 Year Yield & -0.074 & -0.090 & -0.080 & -0.006 & -0.054 & -0.069 & -0.052 & -0.055 \\
7 Year Yield & -0.192 & -0.180 & -0.194 & -0.164 & -0.174 & -0.174 & -0.172 & -0.175 \\
8 Year Yield & -0.283 & -0.254 & -0.284 & -0.298 & -0.274 & -0.264 & -0.274 & -0.274 \\
9 Year Yield & -0.353 & -0.316 & -0.355 & -0.402 & -0.356 & -0.341 & -0.359 & -0.356 \\
10 Year Yield & -0.406 & -0.371 & -0.413 & -0.473 & -0.423 & -0.408 & -0.431 & -0.423
\end{tabular}


Table 8. Regressions of yields on German yields

\begin{tabular}{rllll}
\multicolumn{5}{c}{} \\
\multicolumn{5}{c}{$\begin{array}{c}\text { A. Two-year yields } \\
\text { Post-EMU }\end{array}$} \\
\cline { 2 - 5 } GE & BE & FI & DK & SE \\
\cline { 2 - 6 } Constant & $1.007^{* * *}$ & $1.054^{* * *}$ & $1.007^{* * *}$ & $0.781^{* * *}$ \\
& $(0.002)$ & $(0.004)$ & $(0.003)$ & $(0.011)$ \\
& $-0.059^{* * *}$ & $-0.128^{* * *}$ & $0.027^{* * *}$ & $0.734^{* * *}$ \\
Observations & $(0.006)$ & $(0.010)$ & $(0.010)$ & $(0.041)$ \\
R-squared & 1323 & 1323 & 1323 & 1323 \\
& 1.00 & 0.98 & 0.99 & 0.72
\end{tabular}

\begin{tabular}{|c|c|c|c|c|}
\hline & \multicolumn{4}{|c|}{$\begin{array}{l}\text { B. Five-year yields } \\
\text { Post-EMU }\end{array}$} \\
\hline & $\mathrm{BE}$ & $\mathrm{FI}$ & DK & SE \\
\hline GE & $\begin{array}{l}0.995^{* * *} \\
(0.003)\end{array}$ & $\begin{array}{l}1.021^{* * *} \\
(0.003)\end{array}$ & $\begin{array}{l}1.008^{* * *} \\
(0.006)\end{array}$ & $\begin{array}{l}0.820^{* * *} \\
(0.015)\end{array}$ \\
\hline Constant & $\begin{array}{l}-0.001 \\
(0.010)\end{array}$ & $\begin{array}{l}-0.096^{* * *} \\
(0.010)\end{array}$ & $\begin{array}{l}-0.011 \\
(0.021)\end{array}$ & $\begin{array}{l}0.801^{* * *} \\
(0.056)\end{array}$ \\
\hline Observations & 1323 & 1323 & 1323 & 1323 \\
\hline R-squared & 0.99 & 0.99 & 0.96 & 0.63 \\
\hline
\end{tabular}

\begin{tabular}{rlllll}
\multicolumn{5}{c}{} & \multicolumn{4}{c}{$\begin{array}{c}\text { C. Ten-year yields } \\
\text { Post-EMU }\end{array}$} \\
\cline { 2 - 6 } GE & FI & DK & SE \\
\cline { 2 - 5 } Constant & $0.964^{* * *}$ & $0.951^{* * *}$ & $1.025^{* * *}$ & $1.021^{* * *}$ \\
& $(0.006)$ & $(0.010)$ & $(0.009)$ & $(0.020)$ \\
& $0.282^{* * *}$ & $0.208^{* * *}$ & $0.063^{*}$ & 0.084 \\
Observations & $(0.023)$ & $(0.037)$ & $(0.035)$ & $(0.074)$ \\
R-squared & 1323 & 1323 & 1323 & 1323 \\
& 0.91 & 0.83 & 0.87 & 0.61 \\
& Notes. Robust standard errors in parentheses \\
& $*$ significant at 10\%; ** significant at 5\%; *** significant at \\
& &
\end{tabular}


Figure 1. Time Series of Constant Maturity Yields

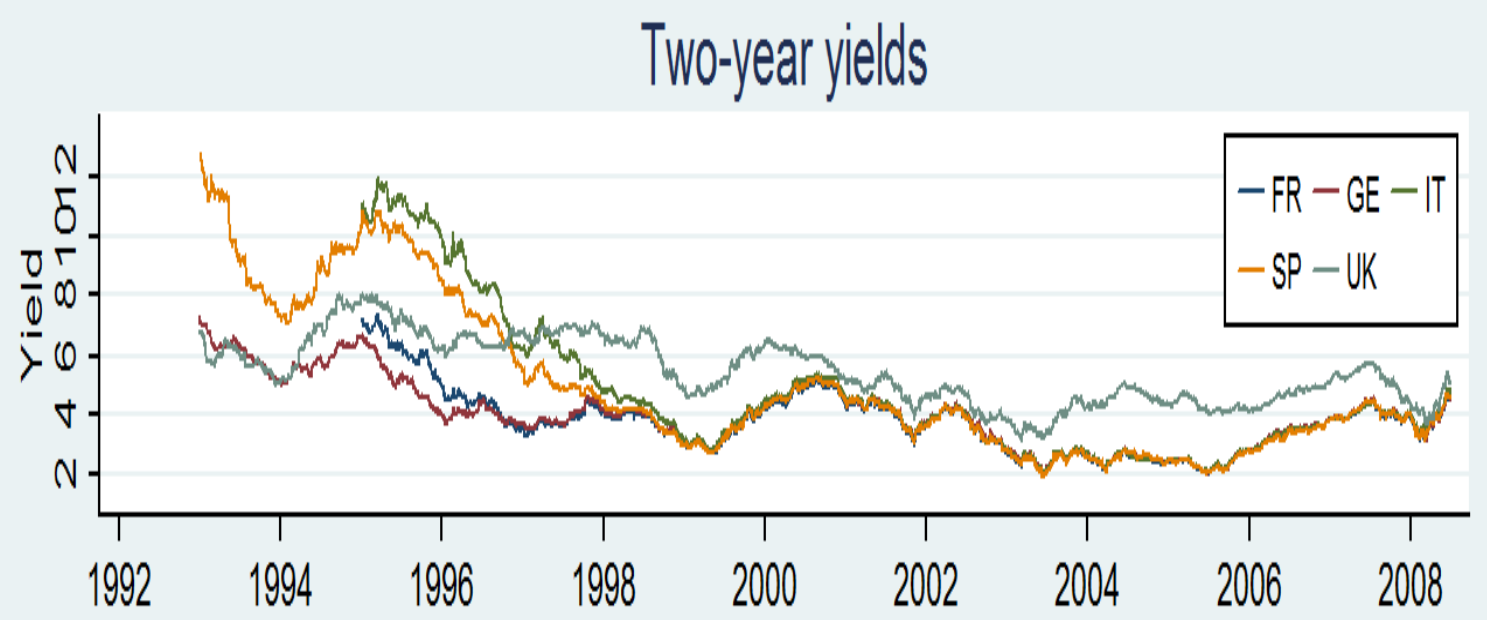

Five-year yields

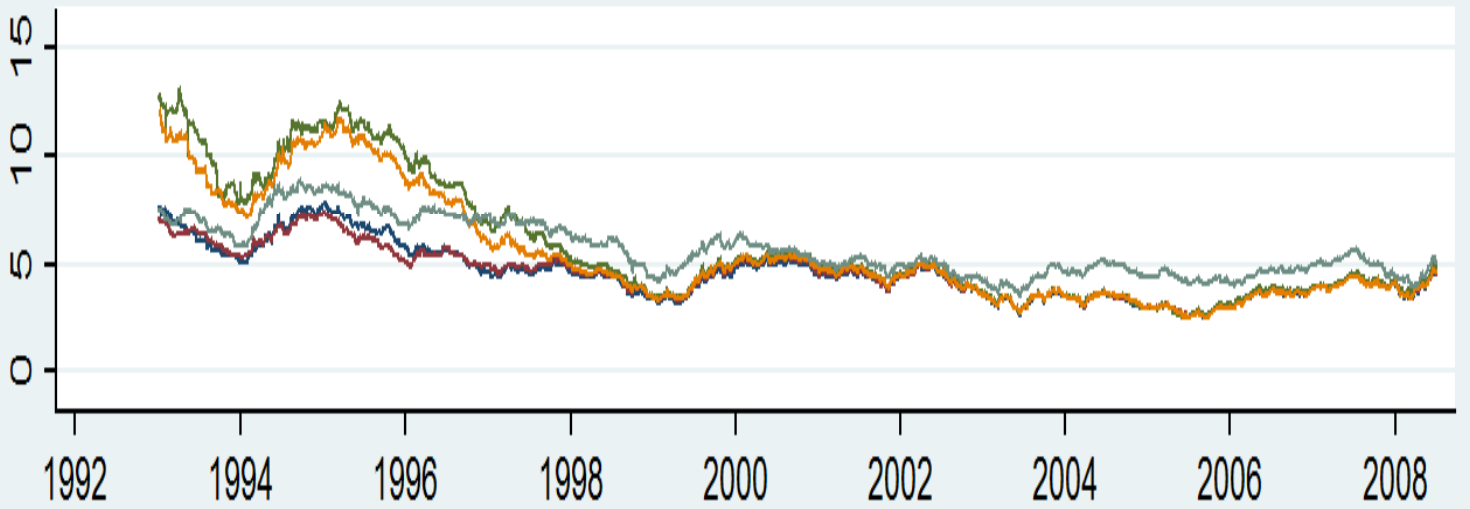

Ten-year yieds

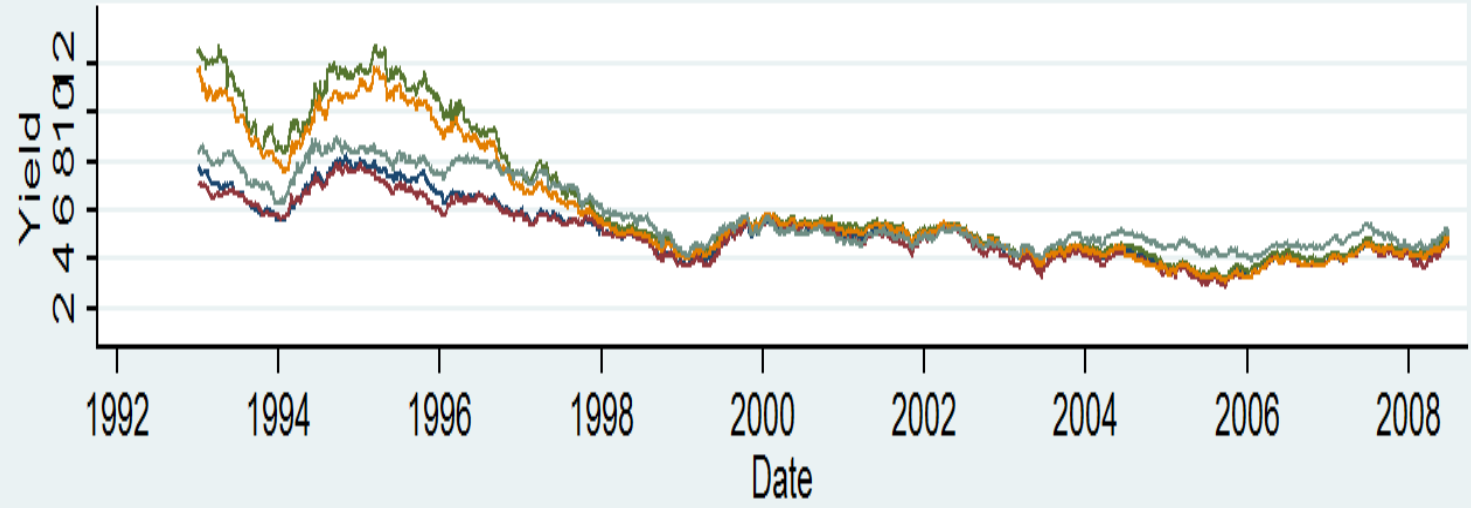


Figure 2. Response of yields to macroeconomic surprises

\section{A. 2-year yields}
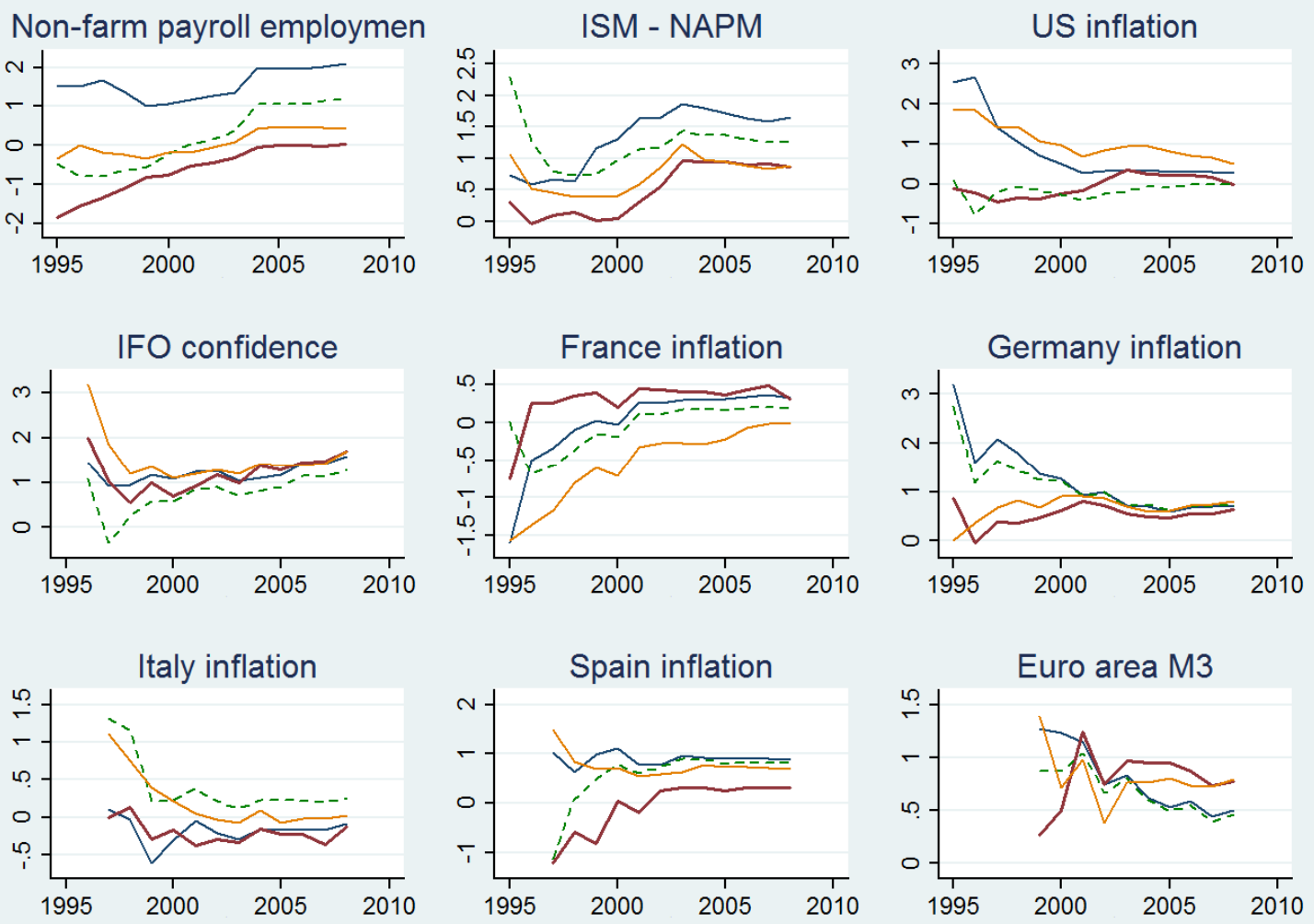

\section{B. 5-year yields}

Non-farm payroll employmen

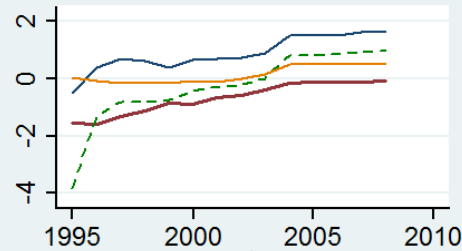

IFO confidence

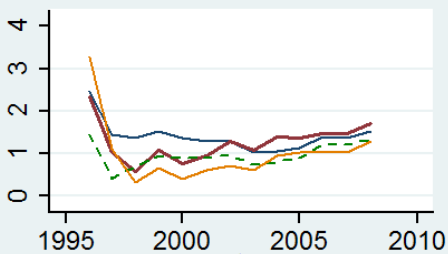

Italy inflation

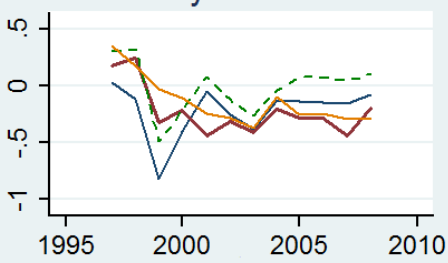

ISM - NAPM

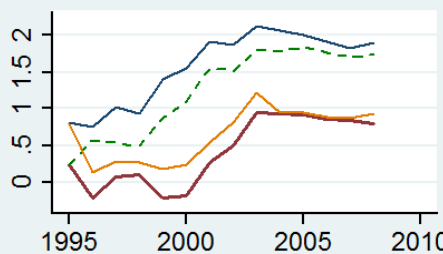

France inflation

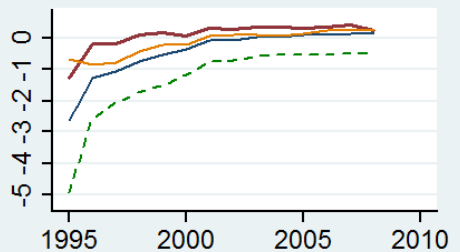

Spain inflation

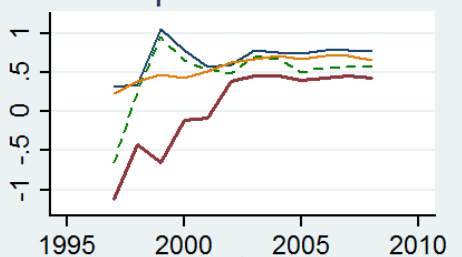

US inflation

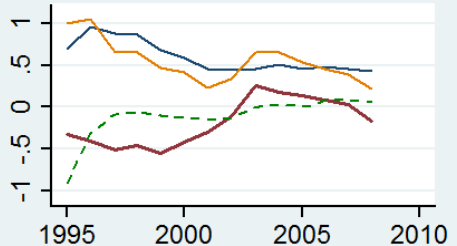

Germany inflation

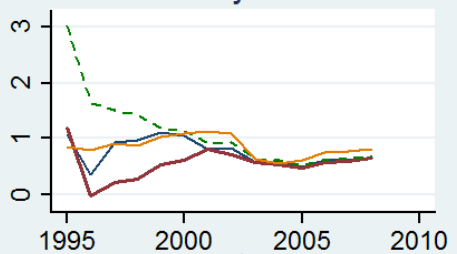

Euro area $\mathrm{M} 3$

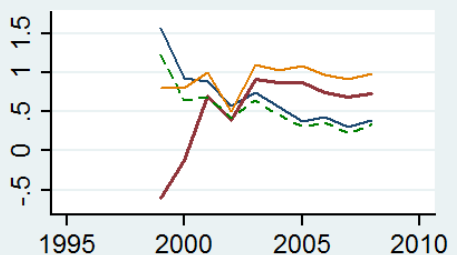




\section{10-year yields}
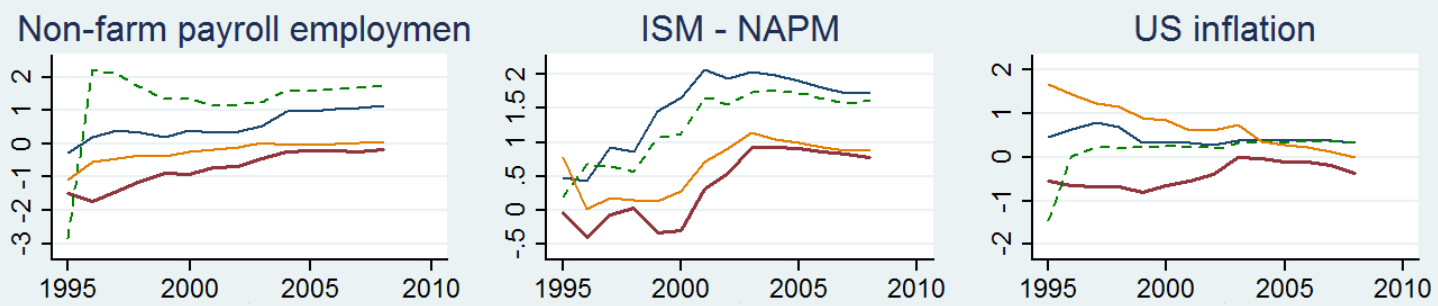

IFO confidence

France inflation
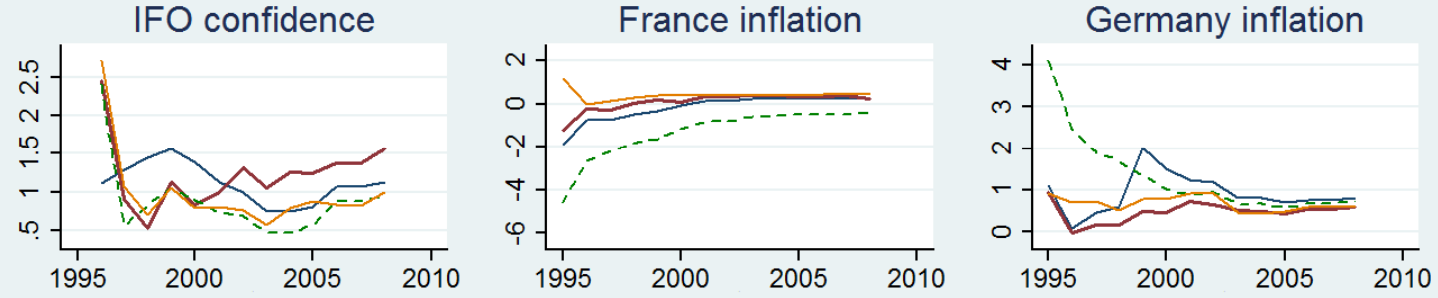

Italy inflation

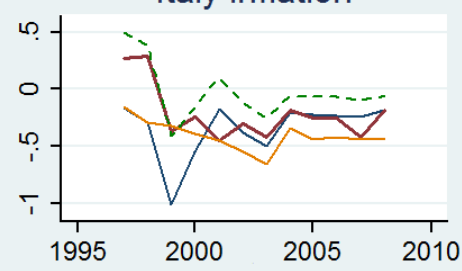

Spain inflation

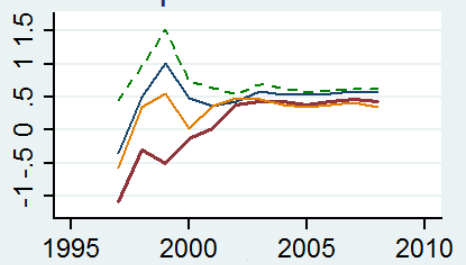

Euro area M3

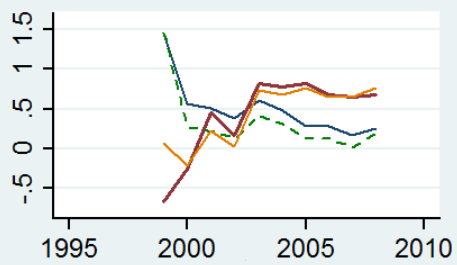

Note. Slope coefficients from rolling regressions with four-year windows, as described in text. 
Figure 3. Heterogeneity in the effects of macroeconomic surprises, 2-, 5-, 10-year yields
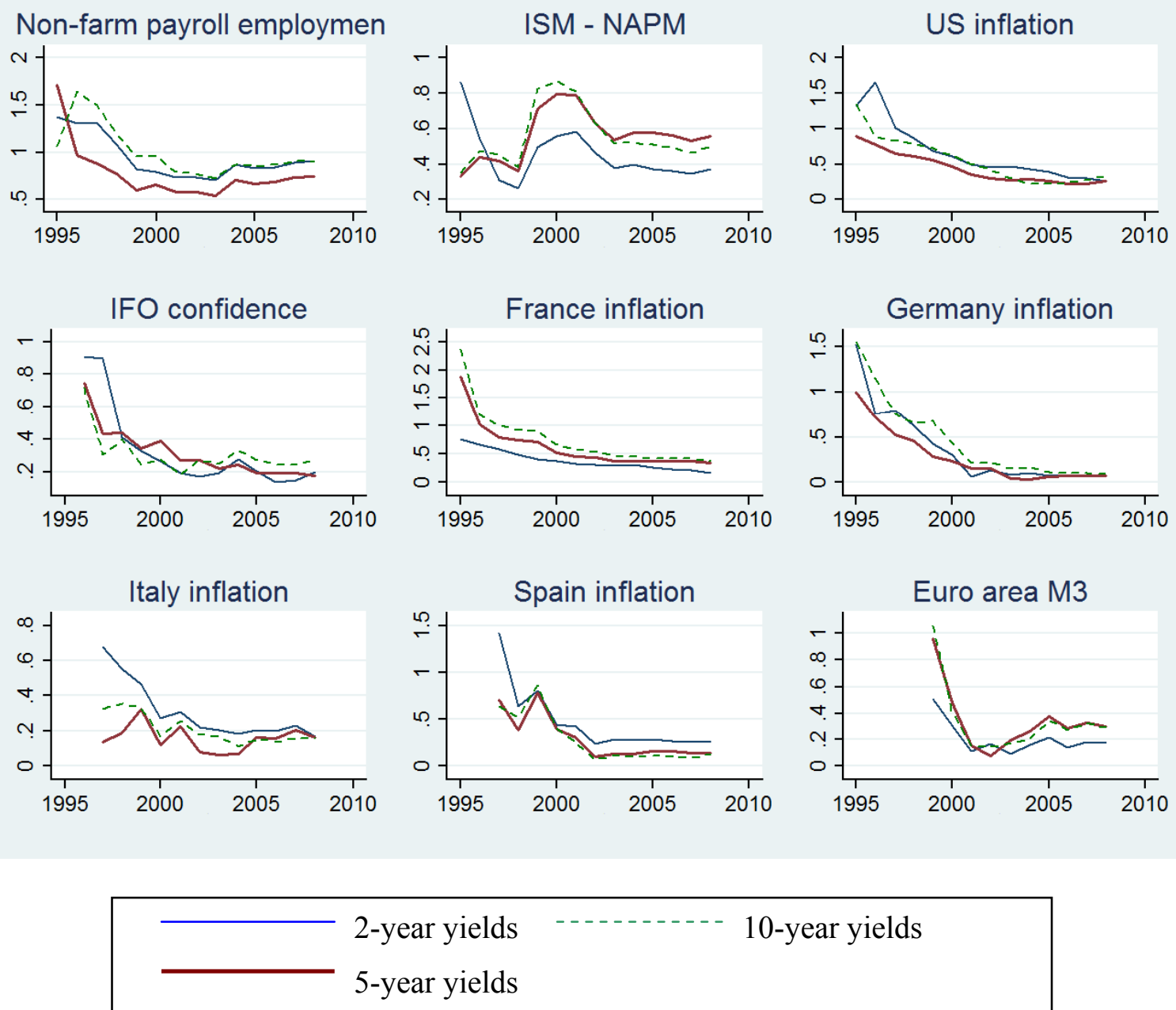

Notes: The figure shows the standard deviation in the response coefficients $\beta$ across the four euro area countries in the sample (France, Germany, Italy, Spain) from $\Delta y_{t}^{i, j}=\alpha^{i, j}+\sum_{k=1}^{K} \sum_{l=1}^{L_{k}} \beta_{l, k}^{i, j}$ Surprise $_{l, k, t}+\varepsilon_{t}^{i, j}$, using a rolling estimation of 4-year windows. 
Figure 4. Constant Maturity Yields for Small-Country Sample

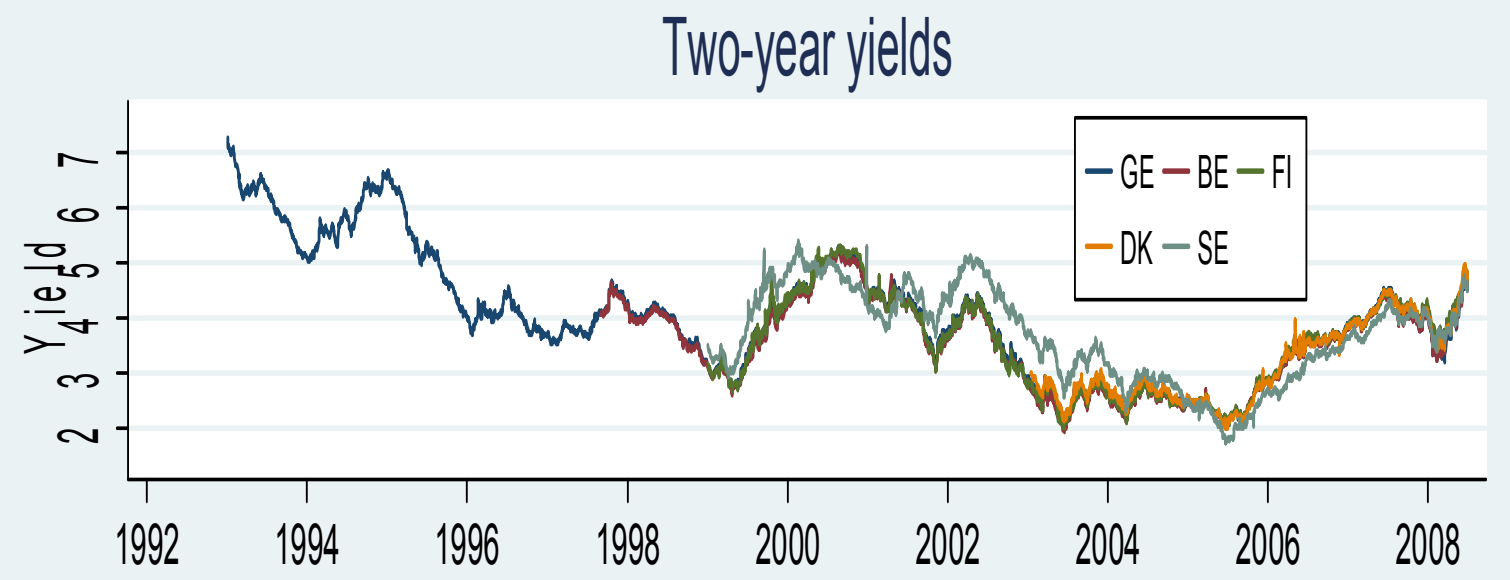

Five-year yields

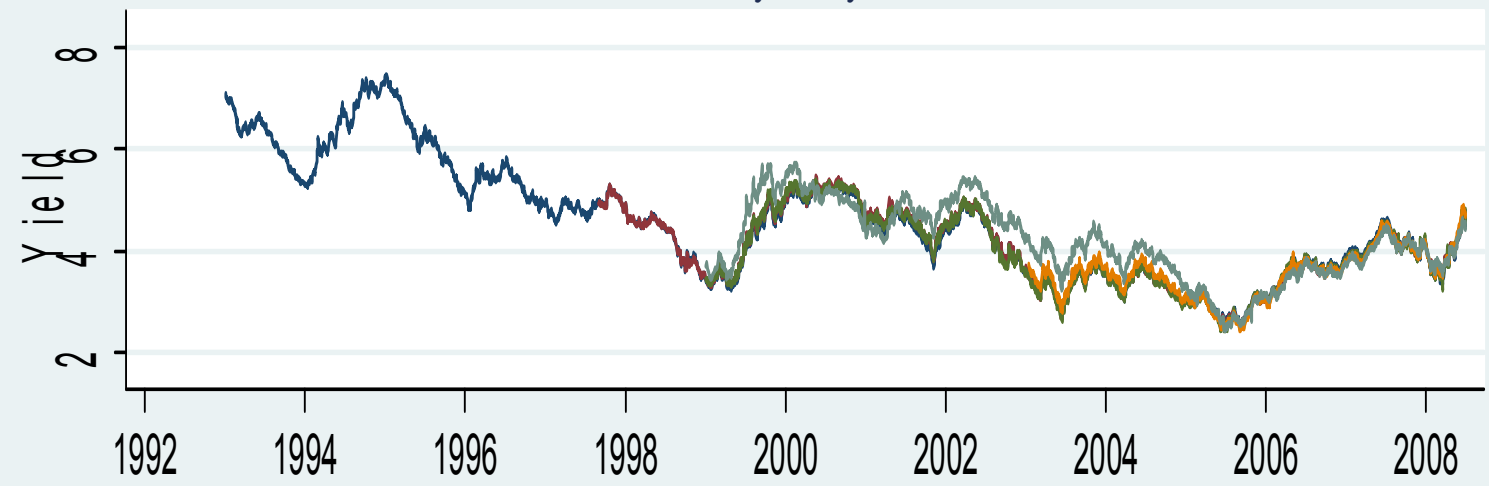

Ten-year yields

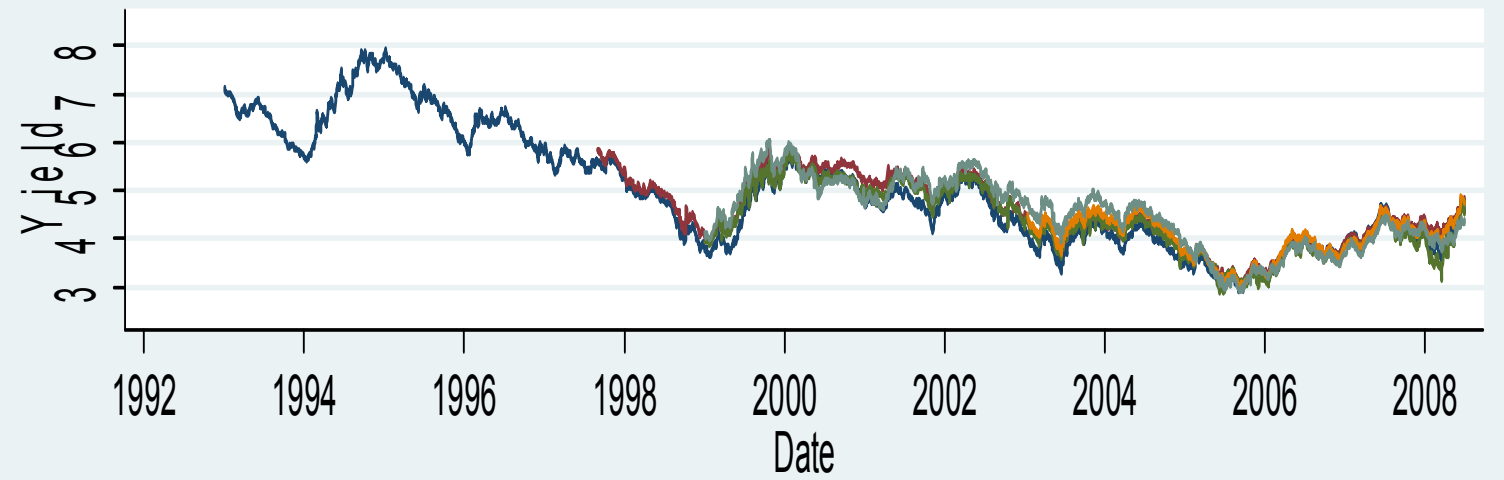


Figure 5. Constant Maturity Yields for Three US States

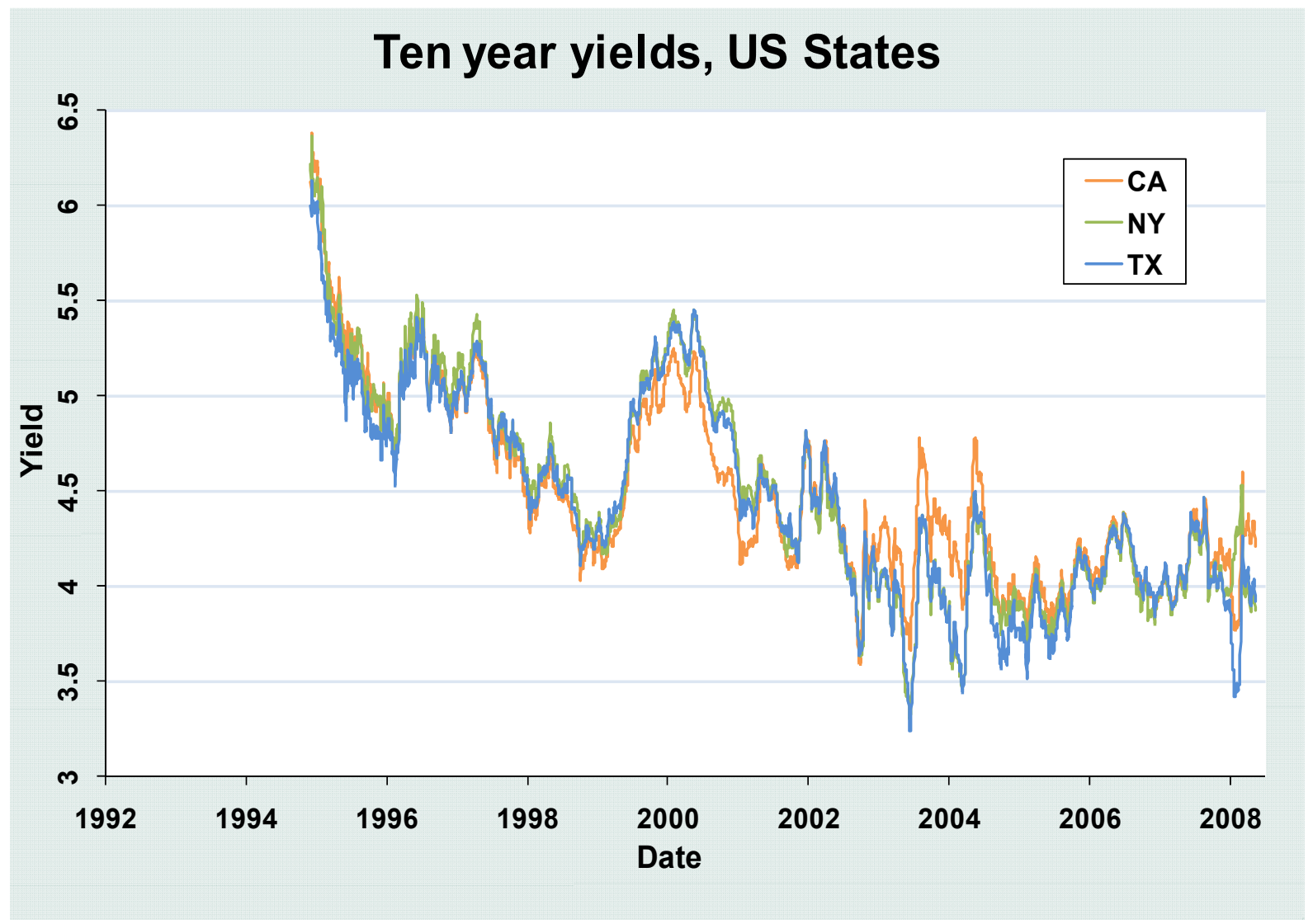




\section{Appendix A. Data Construction}

\section{a. Yields}

The daily smoothed yield curve data comes from the Bank for International Settlements for Germany, Spain, Belgium, Finland, and Sweden. These data have the key BISM.D.HSJA.XX, where XX denotes the different country codes. The BIS did not have daily zero-coupon yield curve data for Denmark, so we obtained these yields directly from the Danmarks Nationalbank. Daily zero-coupon yields for the UK are available from the Bank of England's web page at http://www.bankofengland.co.uk. Italian and French yield curves at daily frequency going back to the early 1990s are not generally available, so we estimated those ourselves, using underlying bond data from Bloomberg Financial Services. The yield curves estimated were of the extended Nelson-Siegel (Svensson) functional form, as described in detail in Gürkaynak, Sack, and Wright (2007). Bloomberg only had bonds with greater than five years to maturity available for early in the period, so we do not compute or use short-term yields (less than five years) before 1995 for France and Italy.

\section{b. Macroeconomic Data Surprises}

Data on US macroeconomic statistical releases and forecasts were collected by Money Market Services up through July 2003, when that company merged with a larger financial institution. Subsequent to July 2003, the same survey was produced again by Action Economics. These data are available for purchase from Haver Analytics as part of the "MMS" series of data at http://www.haver.com. For the UK, we also obtained MMS data from Haver Analytics.

Bloomberg also carries out surveys of expectations for macroeconomic data releases and publishes these together with the realized values. The MMS and Bloomberg numbers agree almost perfectly when they both exist. We used Bloomberg data to fill in gaps in the MMS data late in the period for the US and UK. Data on individual country releases for France, Germany, Italy, and Spain, and the euro area aggregates, also come from Bloomberg. Bloomberg's macroeconomic data release coverage begins in 1996 which limits our macroeconomic data surprises from the continental European countries to this period. Euro area aggregates begin to be reported in 1999. 
Many of the series are reported both as month-on-month (or quarter-on-quarter) and year-on year changes. In these cases, we chose the version that had the greater number of available observations, which typically was the month-on-month version (German M3 was the main exception; in this case we use the year-on-year rates). We have verified that using the yearon-year versions of the announcements does not change the results of our analysis.

\begin{tabular}{|c|c|c|}
\hline \multicolumn{3}{|c|}{ Table A-1. Availability of Surprise Data } \\
\hline Surprise & Begins & Ends \\
\hline US Capa. Util. & Jan-93 & Dec-06 \\
\hline US Cons. Conf & Jan-93 & Dec-06 \\
\hline US CPIX & Jan-93 & Dec-06 \\
\hline US GDP & Jan-93 & Dec-06 \\
\hline US NAPM & Jan-93 & Dec-06 \\
\hline US NonFarm Pay. & Jan-93 & Dec-06 \\
\hline US New Hom. & Feb-93 & Dec-06 \\
\hline US Ret. Sales & Jan-93 & Dec-06 \\
\hline US Unemp. & Jan-93 & Dec-06 \\
\hline UK Avg. Earnings & May-98 & Dec-06 \\
\hline UK GDP & Apr-93 & Nov-06 \\
\hline UK Man. Prod. & Mar-93 & Dec-06 \\
\hline UK PPI & Mar-93 & Dec-06 \\
\hline UK RPIX & Mar-93 & Dec-06 \\
\hline UK Ret. Sales & Mar-93 & Dec-06 \\
\hline EA Bus. Climate & May-99 & Oct-06 \\
\hline EA CPI & Jan-99 & Nov-06 \\
\hline EA Ind. Prod. & Jan-99 & Nov-06 \\
\hline EA M3 & Mar-99 & Nov-06 \\
\hline EA Unemp. & Feb-99 & Nov-06 \\
\hline GE CPI & Mar-93 & Nov-06 \\
\hline GE IFO & Aug-96 & Nov-06 \\
\hline GE Ind. Prod. & Mar-93 & Nov-06 \\
\hline GE M3 & Mar-93 & Jan-99 \\
\hline GE Man. Ord. & Mar-93 & Nov-06 \\
\hline GE Unemp. & Mar-93 & Nov-06 \\
\hline FR Cons. Confid. & Dec-96 & Oct-06 \\
\hline FR CPI & Mar-93 & Nov-06 \\
\hline FR Ind. Prod. & Mar-93 & Nov-06 \\
\hline FR M3 & Mar-93 & Feb-96 \\
\hline FR Unemp & Feb-93 & Oct-06 \\
\hline IT CPI & Jan-97 & Nov-06 \\
\hline IT Ind. Prod. & Mar-97 & Nov-06 \\
\hline IT Unemp. & Jun-97 & Sep-06 \\
\hline SP CPI & Feb-97 & Nov-06 \\
\hline SP Unemp. & Nov-97 & Nov-06 \\
\hline SP. Ind. Prod. & Mar-97 & Nov-06 \\
\hline
\end{tabular}

